\title{
Ancient lineages of arbuscular mycorrhizal fungi provide little plant benefit
}

\author{
Verena Säle ${ }^{1,2,3}$ - Javier Palenzuela ${ }^{4}$ Concepción Azcón-Aguilar ${ }^{4} \cdot$ Iván Sánchez-Castro $^{5}$. \\ Gladstone Alves da Silva $^{6} \cdot$ Benjamin Seitz $^{1} \cdot$ Ewald Sieverding $^{7} \cdot$ Marcel G. A. van der Heijden $^{1,8} \cdot$ Fritz OehI $^{9}$
}

Received: 12 March 2021 / Accepted: 8 July 2021 / Published online: 30 July 2021

(c) The Author(s) 2021

\begin{abstract}
Almost all land plants form symbiotic associations with arbuscular mycorrhizal fungi (AMF). Individual plants usually are colonized by a wide range of phylogenetically diverse AMF species. The impact that different AMF taxa have on plant growth is only partly understood. We screened $44 \mathrm{AMF}$ isolates for their effect on growth promotion and nutrient uptake of leek plants (Allium porrum), including isolates that have not been tested previously. In particular, we aimed to test weather AMF lineages with an ancient evolutionary age differ from relatively recent lineages in their effects on leek plants. The AMF isolates that were tested covered 18 species from all five AMF orders, eight families, and 13 genera. The experiment was conducted in a greenhouse. A soil-sand mixture was used as substrate for the leek plants. Plant growth response to inoculation with AMF varied from -19 to $232 \%$ and depended on isolate, species, and family identity. Species from the ancient families Archaeosporaceae and Paraglomeraceae tended to be less beneficial, in terms of stimulation plant growth and nutrient uptake, than species of Glomeraceae, Entrophosporaceae, and Diversisporaceae, which are considered phylogenetically more recent than those ancient families. Root colonization levels also depended on AMF family. This study indicates that plant benefit in the symbiosis between plants and AMF is linked to fungal identity and phylogeny and it shows that there are large differences in effectiveness of different AMF.
\end{abstract}

Keywords Arbuscular mycorrhizal fungi (AMF) $\cdot$ Evolution $\cdot$ Functional diversity $\cdot$ Phylogeny $\cdot$ Plant benefit

\section{Introduction}

Arbuscular mycorrhizal fungi (AMF) play a key role in ecosystems and promote plant growth and nutrition (Smith and Read 2008; van der Heijden et al. 2015). AMF are abundant

Marcel G.A. van der Heijden and Fritz Oehl are joint last authors

Verena Säle

verena.saele@gmail.com

1 Plant-Soil-Interactions, Agroscope, Reckenholzstrasse 191, CH-8046 Zürich, Switzerland

2 Department of Evolutionary Biology and Environmental Studies, University of Zürich, Winterthurerstrasse 190, CH-8057 Zürich, Switzerland

3 Vegetable-Production Extension, Agroscope Müller-Thurgau-Strasse 29, CH-8820 Wädenswil, Switzerland

4 Departamento de Microbiología del Suelo Y Sistemas Simbióticos, Estación Experimental del Zaidín, CSIC, Profesor Albareda 1, 18008 Granada, Spain in almost all natural soils and have been considered as keystone taxa in soil microbial communities (Banerjee et al. 2019). AMF are able to establish symbioses with the majority of terrestrial plants. In return for photosynthates, the fungi provide several benefits to their host plants. These include increased phosphorus and nitrogen uptake and enhanced

5 Departamento de Microbiología, Universidad de Granada, Campus Universitario de Fuentenueva, 18071 Granada, Spain

6 Departamento de Micologia, CCB, Universidade Federal de Pernambuco, Av. da Engenharia s/n, Cidade Universitária, Recife, PE 50740-600, Brazil

7 Institute of Agricultural Sciences in the Tropics (Hans-Ruthenberg Institute), University of Hohenheim, Garbenstr. 13, 70599 Stuttgart-Hohenheim, Germany

8 Department of Plant and Microbial Biology, University of Zürich, 8057 Zürich, Switzerland

9 Ecotoxicology, Agroscope, Müller-Thurgau-Strasse 29, CH-8820 Wädenswil, Switzerland 
resistance to drought and root pathogens (Jia et al. 2020; Smith and Read 2008; van der Heijden et al. 2015) as well as mitigation of salinity stress (e.g., Evelin et al. 2019). Also, improved soil quality by aggregating soil particles repeatedly has been reported (e.g., Rillig and Mummey 2006). In addition, diverse AMF communities can lead to elevated diversity and productivity of plant communities (Jansa et al. 2008; van der Heijden et al. 1998a). Hence, crop production can profit from these positive effects which might be expressed in higher yield or reduced use of phosphatic fertilizer. The latter is advantageous in view of the growing demand for sustainable strategies in agricultural systems (Bender et al. 2016; Sorensen et al. 2008).

The effectiveness of the symbiosis depends, among other factors, on the combination of plant and AM fungus, soil type, soil fertility, and the origin of the AMF isolates (de Novais et al. 2014; Feddermann et al. 2010; Pringle and Bever 2008). It has been assumed for instance that AMF isolated from polluted sites are advantageous for the bioremediation of such sites (e.g., Cabello 1999; Hildebrandt et al. 2007; Takács 2012), or indigenous AMF isolates are superior to exotic isolates for plant growth promotion (e.g., Estrada et al. 2013; Klironomos 2003; Oliveira et al. 2005; Tchabi et al. 2010). Furthermore, high functional diversity among different AMF species and even among isolates belonging to the same species (Feddermann et al. 2010; Munkvold et al. 2004) has been observed. Because of this high functional diversity, it is important to investigate a wide range of different plant-AMF combinations (Feddermann et al. 2010). For example, some AMF taxa are most efficient to supply nutrients to their host plants, while others provide notable resistance against biotic or abiotic stresses (Fester and Sawers 2011; Verbruggen et al. 2010). Functional traits may be phylogenetically conserved, i.e., symbiotic functions such as plant growth promotion depend on AMF lineages (Powell et al. 2009). A meta-analysis from Hoeksema et al. (2018), however, suggested that AMF phylogeny is not related to plant response; instead, recent diversification among plants explains variation in the arbuscular mycorrhizal symbiosis.

Previous studies have shown that different AMF families and clades significantly affect plant biomass, with some clades having superior effects on host plants, while others have no or weak effects (e.g., Hart and Reader 2002a; Sieverding et al. 2014). For example, van der Heijden et al. (1998a) and Powell et al. (2009) observed that the ancient AMF (e.g., Paraglomus (isolate BEG 21 in van der Heijden et al. 1998a) and Archaeospora (in Powell et al. 2009) are less beneficial in promoting plant growth than more recently evolved AMF including Rhizoglomus and Funneliformis. Nevertheless, so far, it is unclear whether symbiotic benefit is linked to the phylogenetic distances among AMF species and whether those distances can be used to make predictions regarding the growth-promoting properties of AMF. This issue deserves increased attention, especially because there are only a few studies of members of the Paraglomerales and Archaeosporales, despite their widespread occurrence in many ecosystems (Davison et al. 2015). There is one study from Koch et al. (2017) that tested three host plants and 56 isolates, including several members of ancient AMF families (e.g., Archaeospora trappei and Paraglomus occultum). Koch et al. (2017) conclude that host performance cannot be predicted from AM fungus morphology and growth traits. Rather divergent effects on plant growth among isolates within an AM fungus species may be caused by coevolution between co-occurring fungus and plant populations.

The major objective of the present study was to investigate how AMF taxonomic levels and phylogeny affect plant growth and nutrient uptake. In order to test this, we compared 44 AMF isolates, comprising all five glomeromycotan orders, eight of 16 AMF families, and 13 of 48 AMF genera, including several taxa not tested previously in systematic investigations (e.g., Rhizoglomus invermaium, Dominikia compressa, and Cetraspora helvetica). The 44 isolates all had been prepared under similar conditions and were propagated on Hieracium pilosella L. on the same soil-sand substrate for 1 year before screening them on leek. These isolates were characterized morphologically and molecularly using the partial large subunit (LSU) of the ribosomal gene after DNA extraction from spores. We assessed the impact of those different isolates on growth and plant nutrient concentrations of leek (Allium porrum L.) for different levels of taxa, i.e., on the levels of isolates, species, genera, and families. Specifically, we tested whether (i) plant growth and root colonization differs depending on AMF taxa and AMF families; (ii) members of ancient AMF families differed in their effects on plant growth compared to more recently evolved AMF families; and (iii) the phylogenetic placement of AMF isolates could explain their impacts on plant growth. We hypothesized that leek growth as well as nutrient assimilation and root colonizing strategies differ among AMF isolates and species, and even among higher taxa and major phylogenetic clades. In addition, we hypothesize that ancient AMF are less mutualistic in terms of plant growth stimulation than relatively recently evolved AMF families.

\section{Materials and methods}

\section{AMF isolates for screening effects on leek growth}

Between July 2011 and June 2012, 150 monosporal and 90 multisporal cultures were grown on H. pilosella in the Swiss collection for arbuscular mycorrhizal fungi (SAF) (https:// www.agroscope.ch/saf), as described in Tchabi et al. (2010). The substrate for AMF propagation was a mixture of three 
parts Terragreen (American aluminum oxide, Oil Dry US special, type III R) and one part Loess with the following parameters: $\mathrm{pH}-\mathrm{H}_{2} \mathrm{O} 6.8$; organic carbon $3.0 \mathrm{~g} \mathrm{~kg}^{-1}$; available $\mathrm{P}$ (P-double lactate) $15.6 \mathrm{mg} \mathrm{kg}^{-1}$; available $\mathrm{K}$ (Naacetate) $350 \mathrm{mg} \mathrm{kg}^{-1}$.

Besides being of monosporal or multisporal origin, all isolates were propagated identically in the glasshouse. After initial propagation, the inocula were air-dried and stored for 12 months before inoculation to leek (Allium porrum L.). Forty-four AMF isolates were selected from the SAF for the screening experiment on leek, comprising 18 AMF species, 13 genera, eight families, five orders, and three AMF classes. Per AMF species, one to four isolates were selected, whenever possible deriving from different isolation sites (Table 1). Except the two Scutellospora calospora isolates, which were derived from soils in southwestern Germany, all isolates originated from Swiss soils. Thirty-five isolates ("11-FO..." isolates in Table 1) were from monosporal AMF cultures, established as described in Tchabi et al. (2010). Two other isolates (of Sc. calospora) were derived from one monosporal culture established in 2001 ("01-FO..." isolates) and were propagated in two separate pots between July 2011 and June 2012 especially for the leek screening experiment. Seven additional isolates (one of Diversispora celata, and two each of Gigaspora margarita, Cetraspora helvetica, and Paraglomus laccatum) were derived from multiple spore cultures originally established in 1994-2002 (see Oehl et al. 2010, 2014a, b; van der Heijden et al. 1998b) and were propagated for our purposes as mentioned above for Sc. calospora. The inocula were checked for their spore densities. To create equal preconditions for the non-mycorrhizal treatment, the inoculum for the control derived from an unsuccessful monosporal AMF culture on $H$. pilosella, in which no AMF symbiosis could be established and no AMF spores had been formed.

\section{Morphological characterization of AMF isolates}

Spores of the 44 AMF isolates were extracted from the inocula substrates by wet sieving and decanting followed by sucrose gradient centrifugation and counted in Petri dishes under a dissecting microscope as described in Sieverding (1991). The spores were morphologically identified from specimens mounted in polyvinyl-lacto-glycerol (PVLG; Koske and Tessier 1983) and a mixture of PVLG and Melzer's reagent (Brundrett et al. 1994). Reference slides of the isolates were deposited at the mycological herbarium of ETH Zurich $(\mathrm{Z}+\mathrm{ZT})$. For morphological spore identification, the identification manual of Błaszkowski (2012) for Glomeromycota was used and was based on the classification system of Oehl et al. (2011b), considering the most recent updates (e.g., Baltruschat et al. 2019; Błaszkowski et al. 2015, 2018a, b; Błaszkowski et al. 2019; Wijayawardene et al. 2020).
The identifications of the $44 \mathrm{AMF}$ isolates resulted in 18 species from eight families. The isolates from the order Glomerales were most numerous and belonged to the families Glomeraceae and Entrophosporaceae (Table 1).

\section{Molecular characterization of the AMF isolates}

A subset of the AMF spores extracted was used for molecular analyses as described in Palenzuela et al. (2015). Five spores were isolated from each AMF inoculum originating from propagations on $\mathrm{H}$. pilosella in the glasshouses of Agroscope in Zurich-Reckenholz. Spores were surfacesterilized with chloramine $\mathrm{T}(2 \%)$ and streptomycin $(0.02 \%$; Mosse 1962), and all five together were crushed with a sterile disposable micropestle in $23 \mu \mathrm{l}$ milli-Q water as described in Palenzuela et al. (2013). Deoxyribonucleic acid (DNA) amplification of the crude extracts was performed in an automated thermal cycler (Gene Amp PCR System 2400, Perkin-Elmer, Foster City, California) using pureTaq ReadyTo-Go PCR Beads (Amersham Biosciences Europe GmbH, Germany) by following the manufacturer's instructions. A two-step polymerase chain reaction (PCR) was conducted to increase the specificity of amplification. A 1500-bp fragment was amplified comprising the SSU end, ITS1, 5.8S, ITS2, and partial LSU rDNA using the SSUmAf/LSUmAr and SSUmCf/LSUmBr primers consecutively (Krüger et al. 2009; Oehl et al. 2019a, b). PCR products were analyzed by electrophoresis in 1.2\% agarose gels stained with Gel Red $^{\mathrm{TM}}$ (Biotium Inc., Hayward, CA, USA) and viewed by UV illumination. Amplicons of the expected size were purified using the Illustra GFX PCR DNA and Gel Band Purification kit and were directly sequenced. For those for which not fair sequences were obtained, a portion of the purified PCR product was cloned into the PCR 2.1 vector (Invitrogen, Carlsbad, CA, USA), and transformed into One shot $(\odot$ TOP10 chemically competent Escherichia coli cells. After plasmid isolation from transformed cells, the cloned DNA fragments were sequenced with vector primers (White et al. 1990) in both directions by Taq polymerase cycle sequencing on an automated DNA sequencer (Perkin-Elmer ABI Prism 373).

DNA sequences are deposited in the NCBI GenBank (www.ncbi.nlm.nih.gov/genbank/); accession numbers are given in Table 1.

\section{Phylogenetic analyses}

The phylogeny was reconstructed by analyses of the partial LSU rDNA. The AM fungal sequences obtained were aligned with other Glomeromycota sequences from GenBank in ClustalX2 (Larkin et al. 2007). Boletus edulis Bull. and Mortierella ambigua B. S. Mehrotra were included as an outgroup. Prior to phylogenetic analysis, the model 
Table 1 List of AMF isolates used in this study together with reference collection numbers $(\mathrm{SAF}=$ Swiss collection of arbuscular mycorrhizal fungi; original accession number) and information on the

\begin{tabular}{|c|c|c|c|c|c|c|c|c|c|}
\hline $\begin{array}{l}\text { Order } \\
\text { Family } \\
\text { Species }\end{array}$ & Isolate & $\begin{array}{l}\text { SAF acces- } \\
\text { sion }\end{array}$ & $\begin{array}{l}\text { Original } \\
\text { accession }\end{array}$ & $\begin{array}{l}\text { NCBI } \\
\text { GenBank } \\
\text { accession }\end{array}$ & $\begin{array}{l}\text { Village and } \\
\text { canton of } \\
\text { origin in } \\
\text { Switzerland }\end{array}$ & $\begin{array}{l}\text { Land use at } \\
\text { origin site }\end{array}$ & Soil pH & $\begin{array}{l}\text { In pure } \\
\text { culture } \\
\text { since }\end{array}$ & $\begin{array}{l}\text { Soil type }{ }^{1} \text { at } \\
\text { origin }\end{array}$ \\
\hline \multicolumn{10}{|l|}{ Glomerales } \\
\hline \multicolumn{10}{|l|}{ Glomeraceae } \\
\hline $\begin{array}{l}\text { Oehlia } \\
\text { diaphana }\end{array}$ & O.dia1 & SAF106 & 11-FO106 & MN996942 & $\begin{array}{l}\text { Uettlingen } \\
\text { BE }\end{array}$ & $\begin{array}{l}\text { Arable Field } \\
\text { (Winter } \\
\text { Wheat) }\end{array}$ & 5.3 & 2011 & $\begin{array}{l}\text { Eutric Cam- } \\
\text { bisol }\end{array}$ \\
\hline $\begin{array}{l}\text { Oehlia } \\
\text { diaphana }\end{array}$ & O.dia2 & SAF107 & 11-FO290 & MN996943 & Graswil BE & $\begin{array}{l}\text { Arable field } \\
\text { (winter } \\
\text { barley) }\end{array}$ & 5.6 & 2011 & $\begin{array}{l}\text { Eutric Cam- } \\
\text { bisol }\end{array}$ \\
\hline $\begin{array}{l}\text { Oehlia } \\
\text { diaphana }\end{array}$ & O.dia3 & SAF108 & 11-FO292 & MN996944 & Graswil BE & $\begin{array}{l}\text { Arable field } \\
\text { (winter } \\
\text { barley) }\end{array}$ & 5.6 & 2011 & $\begin{array}{l}\text { Eutric Cam- } \\
\text { bisol }\end{array}$ \\
\hline $\begin{array}{c}\text { Rhizoglomus } \\
\text { irregulare }\end{array}$ & R.irr1 & SAF130 & 11-FO113 & MN996945 & $\begin{array}{l}\text { Uettlingen } \\
\text { BE }\end{array}$ & $\begin{array}{l}\text { Arable field } \\
\text { (winter } \\
\text { wheat) }\end{array}$ & 5.3 & 2011 & Haplic Luvisol \\
\hline $\begin{array}{l}\text { Rhizoglomus } \\
\text { irregulare }\end{array}$ & R.irr2 & SAF131 & 11-FO190 & MN996946 & Frick AG & $\begin{array}{l}\text { Arable field } \\
\text { (winter } \\
\text { wheat) }\end{array}$ & 7.6 & 2011 & $\begin{array}{l}\text { Vertic Cam- } \\
\text { bisol }\end{array}$ \\
\hline $\begin{array}{c}\text { Rhizoglomus } \\
\text { irregulare }\end{array}$ & R.irr3 & SAF170 & 11-FO420 & MN996947 & Langnau BE & $\begin{array}{l}\text { Permanent } \\
\text { grassland }\end{array}$ & 5.5 & 2011 & $\begin{array}{l}\text { Eutric Cam- } \\
\text { bisol }\end{array}$ \\
\hline $\begin{array}{c}\text { Rhizoglomus } \\
\text { irregulare }\end{array}$ & R.irr4 & SAF96 & 11-FO181 & MN996948 & Frick AG & $\begin{array}{l}\text { Arable field } \\
\text { (winter } \\
\text { wheat) }\end{array}$ & 7.6 & 2011 & $\begin{array}{l}\text { Vertic Cam- } \\
\text { bisol }\end{array}$ \\
\hline $\begin{array}{l}\text { Rhizoglomus } \\
\text { invermaium }\end{array}$ & R.inv1 & SAF205 & 11-FO84 & LN624111-12 & $\begin{array}{l}\text { Hindelbank } \\
\text { BE }\end{array}$ & $\begin{array}{l}\text { Arable field } \\
\text { (grass-clo- } \\
\text { ver) }\end{array}$ & 7.1 & 2011 & $\begin{array}{l}\text { Eutric Cam- } \\
\text { bisol }\end{array}$ \\
\hline $\begin{array}{l}\text { Rhizoglomus } \\
\text { invermaium }\end{array}$ & R.inv2 & SAF206 & 11-FO424 & MN996965 & Langnau BE & $\begin{array}{l}\text { Permanent } \\
\text { grassland }\end{array}$ & 5.5 & 2011 & $\begin{array}{l}\text { Eutric Cam- } \\
\text { bisol }\end{array}$ \\
\hline $\begin{array}{l}\text { Rhizoglomus } \\
\text { invermaium }\end{array}$ & R.inv3 & SAF207 & 11-FO432 & & Rubigen BE & $\begin{array}{l}\text { Permanent } \\
\text { grassland }\end{array}$ & 5.8 & 2011 & $\begin{array}{l}\text { Eutric Cam- } \\
\text { bisol }\end{array}$ \\
\hline $\begin{array}{l}\text { Rhizoglomus } \\
\text { invermaium }\end{array}$ & R.inv4 & SAF147 & 11-FO336 & MN996959 & Rubigen BE & $\begin{array}{l}\text { Permanent } \\
\text { grassland }\end{array}$ & 5.8 & 2011 & $\begin{array}{l}\text { Eutric Cam- } \\
\text { bisol }\end{array}$ \\
\hline $\begin{array}{l}\text { Funneliformis } \\
\text { mosseae }\end{array}$ & F.mos1 & SAF87 & 11-FO85 & MN996949 & $\begin{array}{l}\text { Hindelbank } \\
\text { BE }\end{array}$ & $\begin{array}{l}\text { Arable field } \\
\text { (grass-clo- } \\
\text { ver) }\end{array}$ & 7.1 & 2011 & Haplic Luvisol \\
\hline $\begin{array}{l}\text { Funneliformis } \\
\text { mosseae }\end{array}$ & F.mos 2 & SAF139 & 11-FO239 & MN996950 & Graswil BE & $\begin{array}{l}\text { Arable field } \\
\text { (winter } \\
\text { barley) }\end{array}$ & 5.6 & 2011 & Haplic Luvisol \\
\hline $\begin{array}{l}\text { Funneliformis } \\
\text { mosseae }\end{array}$ & F.mos3 & SAF160 & 11-FO418 & MN996951 & Langnau BE & $\begin{array}{l}\text { Permanent } \\
\text { grassland }\end{array}$ & 5.5 & 2011 & $\begin{array}{l}\text { Eutric Cam- } \\
\text { bisol }\end{array}$ \\
\hline $\begin{array}{c}\text { Funneliformis } \\
\text { caledonius }\end{array}$ & F.cal & SAF111 & 11-FO269 & MN996952 & Graswil BE & $\begin{array}{l}\text { Arable field } \\
\text { (winter } \\
\text { barley) }\end{array}$ & 5.6 & 2011 & Haplic Luvisol \\
\hline $\begin{array}{l}\text { Funneliformis } \\
\text { fragilistratus }\end{array}$ & F.fra1 & SAF109 & 11-FO185 & & Frick AG & $\begin{array}{l}\text { Arable field } \\
\text { (winter } \\
\text { wheat) }\end{array}$ & 7.6 & 2011 & $\begin{array}{l}\text { Vertic Cam- } \\
\text { bisol }\end{array}$ \\
\hline $\begin{array}{l}\text { Funneliformis } \\
\text { fragilistratus }\end{array}$ & F.fra2 & SAF110 & 11-FO193 & MN996960 & Frick AG & $\begin{array}{l}\text { Arable field } \\
\text { (winter } \\
\text { wheat) }\end{array}$ & 7.6 & 2011 & $\begin{array}{l}\text { Vertic Cam- } \\
\text { bisol }\end{array}$ \\
\hline $\begin{array}{l}\text { Septoglomus } \\
\text { nigrum }\end{array}$ & Se.nig1 & SAF86 & 11-FO61 & MK234700 & $\begin{array}{l}\text { Niederösch } \\
\text { BE }\end{array}$ & $\begin{array}{l}\text { Permanent } \\
\text { grassland }\end{array}$ & 5.7 & 2011 & Haplic Luvisol \\
\hline
\end{tabular}

original isolation sites of the AMF isolates. Except two isolates from Germany, all other isolates originated from soils in Switzerland 
Table 1 (continued)

\begin{tabular}{|c|c|c|c|c|c|c|c|c|c|}
\hline $\begin{array}{l}\text { Order } \\
\text { Family } \\
\text { Species }\end{array}$ & Isolate & $\begin{array}{l}\text { SAF acces- } \\
\text { sion }\end{array}$ & $\begin{array}{l}\text { Original } \\
\text { accession }\end{array}$ & $\begin{array}{l}\text { NCBI } \\
\text { GenBank } \\
\text { accession }\end{array}$ & $\begin{array}{l}\text { Village and } \\
\text { canton of } \\
\text { origin in } \\
\text { Switzerland }\end{array}$ & $\begin{array}{l}\text { Land use at } \\
\text { origin site }\end{array}$ & Soil pH & $\begin{array}{l}\text { In pure } \\
\text { culture } \\
\text { since }\end{array}$ & $\begin{array}{l}\text { Soil type }{ }^{1} \text { at } \\
\text { origin }\end{array}$ \\
\hline $\begin{array}{l}\text { Septoglomus } \\
\text { nigrum }\end{array}$ & Se.nig2 & SAF175 & 11-FO471 & MK234701 & Rubigen BE & $\begin{array}{l}\text { Arable field } \\
\text { (winter } \\
\text { barley) }\end{array}$ & 7.1 & 2011 & $\begin{array}{l}\text { Eutric Cam- } \\
\text { bisol }\end{array}$ \\
\hline $\begin{array}{l}\text { Dominikia } \\
\text { compressa }\end{array}$ & Do.com1 & SAF145 & 11-FO332 & & Rubigen BE & $\begin{array}{l}\text { Permanent } \\
\text { grassland }\end{array}$ & 5.8 & 2011 & $\begin{array}{l}\text { Eutric Cam- } \\
\text { bisol }\end{array}$ \\
\hline $\begin{array}{l}\text { Dominikia } \\
\text { compressa }\end{array}$ & Do.com 2 & SAF203 & 11-FO352 & $\begin{array}{l}\text { HG798895- } \\
\quad 99\end{array}$ & Rubigen BE & $\begin{array}{l}\text { Permanent } \\
\text { grassland }\end{array}$ & 5.8 & 2011 & $\begin{array}{l}\text { Eutric Cam- } \\
\text { bisol }\end{array}$ \\
\hline \multicolumn{10}{|c|}{ Entrophosporaceae (late synonym Claroideoglomeraceae ${ }^{2}$ ) } \\
\hline $\begin{array}{l}\text { Claroideo- } \\
\text { glomus } \\
\text { candidum }\end{array}$ & Cl.can & SAF112 & 11-FO411 & MN996953 & Langnau BE & $\begin{array}{l}\text { Permanent } \\
\text { grassland }\end{array}$ & 5.5 & 2011 & $\begin{array}{l}\text { Eutric Cam- } \\
\text { bisol }\end{array}$ \\
\hline $\begin{array}{l}\text { Claroideo- } \\
\text { glomus } \\
\text { claroideum }\end{array}$ & Cl.cla1 & SAF92 & 11-FO55 & MN996961 & $\begin{array}{l}\text { Niederösch } \\
\text { BE }\end{array}$ & $\begin{array}{l}\text { Permanent } \\
\text { grassland }\end{array}$ & 5.7 & 2011 & Haplic Luvisol \\
\hline $\begin{array}{l}\text { Claroideo- } \\
\text { glomus } \\
\text { claroideum }\end{array}$ & Cl.cla2 & SAF181 & 11-FO94 & & $\begin{array}{l}\text { Hindelbank } \\
\text { BE }\end{array}$ & $\begin{array}{l}\text { Permanent } \\
\text { grassland }\end{array}$ & 7.1 & 2011 & Haplic Luvisol \\
\hline $\begin{array}{l}\text { Claroideo- } \\
\text { glomus } \\
\text { claroideum }\end{array}$ & Cl.cla3 & SAF166 & 11-FO370 & & Bantigen BE & $\begin{array}{l}\text { Arable field } \\
\text { (grass-clo- } \\
\text { ver) }\end{array}$ & 6.2 & 2011 & Haplic Luvisol \\
\hline $\begin{array}{l}\text { Entrophos- } \\
\text { pora infre- } \\
\text { quens }\end{array}$ & E.inf1 & SAF209 & 11-FO321 & & Bantigen BE & $\begin{array}{l}\text { Arable field } \\
\text { (grass-clo- } \\
\text { ver) }\end{array}$ & 6.2 & 2011 & $\begin{array}{l}\text { Eutric Cam- } \\
\text { bisol }\end{array}$ \\
\hline $\begin{array}{l}\text { Entrophos- } \\
\text { pora infre- } \\
\text { quens }\end{array}$ & E.inf2 & SAF210 & 11-FO313 & & Bantigen BE & $\begin{array}{l}\text { Arable field } \\
\text { (grass-clo- } \\
\text { ver) }\end{array}$ & 6.2 & 2011 & $\begin{array}{l}\text { Eutric Cam- } \\
\text { bisol }\end{array}$ \\
\hline \multicolumn{10}{|l|}{$\begin{array}{l}\text { Diversispo- } \\
\text { rales }\end{array}$} \\
\hline \multicolumn{10}{|l|}{$\begin{array}{l}\text { Diversispo- } \\
\text { raceae }\end{array}$} \\
\hline $\begin{array}{l}\text { Diversispora } \\
\text { celata }\end{array}$ & Di.cel1 & SAF5 & HG-234 & MN996954 & Eschikon $\mathrm{ZH}$ & $\begin{array}{l}\text { Permanent } \\
\text { grassland }\end{array}$ & 7.0 & $2002^{3}$ & Haplic Luvisol \\
\hline $\begin{array}{l}\text { Diversispora } \\
\text { celata }\end{array}$ & Di.cel2 & SAF151 & 11-FO387 & MN996955 & Bantigen BE & $\begin{array}{l}\text { Permanent } \\
\text { grassland }\end{array}$ & 5.3 & 2011 & Haplic Luvisol \\
\hline $\begin{array}{l}\text { Diversispora } \\
\text { celata }\end{array}$ & Di.cel3 & SAF152 & 11-FO403 & MN996956 & Langnau BE & $\begin{array}{l}\text { Permanent } \\
\text { grassland }\end{array}$ & 5.5 & 2011 & Haplic Luvisol \\
\hline $\begin{array}{l}\text { Diversispora } \\
\text { epigaea }\end{array}$ & Di.epil & SAF118 & 11-FO459 & MN996962 & Rubigen BE & $\begin{array}{l}\text { Arable field } \\
\text { (winter } \\
\text { barley) }\end{array}$ & 7.1 & 2011 & $\begin{array}{l}\text { Eutric Cam- } \\
\text { bisol }\end{array}$ \\
\hline $\begin{array}{l}\text { Diversispora } \\
\text { epigaea }\end{array}$ & Di.epi2 & SAF128 & 11-FO338 & MN996963 & Rubigen BE & $\begin{array}{l}\text { Permanent } \\
\text { grassland }\end{array}$ & 5.8 & 2011 & $\begin{array}{l}\text { Eutric Cam- } \\
\text { bisol }\end{array}$ \\
\hline $\begin{array}{l}\text { Diversispora } \\
\text { epigaea }\end{array}$ & Di.epi3 & SAF129 & 11-FO460 & MN996964 & Rubigen BE & $\begin{array}{l}\text { Arable field } \\
\text { (winter } \\
\text { barley) }\end{array}$ & 7.1 & 2011 & $\begin{array}{l}\text { Eutric Cam- } \\
\text { bisol }\end{array}$ \\
\hline \multicolumn{10}{|l|}{ Gigasporales } \\
\hline \multicolumn{10}{|l|}{ Gigasporaceae } \\
\hline $\begin{array}{l}\text { Gigaspora } \\
\text { margarita }\end{array}$ & G.mar1 & SAF14-1 & $\mathrm{JJ}-4$ & & Tänikon TG & Arable field & 6.2 & $2000^{3}$ & Haplic Luvisol \\
\hline $\begin{array}{l}\text { Gigaspora } \\
\text { margarita }\end{array}$ & G.mar2 & SAF14-2 & $\mathrm{JJ}-4$ & & Tänikon TG & Arable field & 6.2 & $2000^{3}$ & Haplic Luvisol \\
\hline \multicolumn{10}{|l|}{ Racocetraceae } \\
\hline $\begin{array}{c}\text { Cetraspora } \\
\text { helvetica }\end{array}$ & Ce.hell & SAF15-1 & JJ17/19 & HM565946 & Tänikon TG & Arable field & 6.2 & $2000^{3}$ & Haplic Luvisol \\
\hline
\end{tabular}


Table 1 (continued)

\begin{tabular}{|c|c|c|c|c|c|c|c|c|c|}
\hline $\begin{array}{l}\text { Order } \\
\text { Family } \\
\text { Species }\end{array}$ & Isolate & $\begin{array}{l}\text { SAF acces- } \\
\text { sion }\end{array}$ & $\begin{array}{l}\text { Original } \\
\text { accession }\end{array}$ & $\begin{array}{l}\text { NCBI } \\
\text { GenBank } \\
\text { accession }\end{array}$ & $\begin{array}{l}\text { Village and } \\
\text { canton of } \\
\text { origin in } \\
\text { Switzerland }\end{array}$ & $\begin{array}{l}\text { Land use at } \\
\text { origin site }\end{array}$ & Soil pH & $\begin{array}{l}\text { In pure } \\
\text { culture } \\
\text { since }\end{array}$ & $\begin{array}{l}\text { Soil type }{ }^{1} \text { at } \\
\text { origin }\end{array}$ \\
\hline $\begin{array}{c}\text { Cetraspora } \\
\text { helvetica }\end{array}$ & Ce.hel2 & SAF15-2 & JJ17/19 & HM565945 & Tänikon TG & Arable field & 6.2 & $2000^{3}$ & Haplic Luvisol \\
\hline \multicolumn{10}{|l|}{$\begin{array}{l}\text { Scutello- } \\
\text { sporaceae }\end{array}$} \\
\hline $\begin{array}{l}\text { Scutellospora } \\
\text { calospora }\end{array}$ & Sc.cal1 & SAF202-1 & 01-FO30 & MN996957 & $\begin{array}{l}\text { Vogtsburg, } \\
\text { Germany }\end{array}$ & Vineyard & 7.7 & $2001^{4}$ & $\begin{array}{l}\text { Eutric Cam- } \\
\text { bisol }\end{array}$ \\
\hline $\begin{array}{c}\text { Scutellospora } \\
\text { calospora }\end{array}$ & Sc.cal2 & SAF202-2 & 01-FO30 & & $\begin{array}{l}\text { Vogtsburg, } \\
\text { Germany }\end{array}$ & Vineyard & 7.7 & $2001^{4}$ & $\begin{array}{l}\text { Eutric Cam- } \\
\text { bisol }\end{array}$ \\
\hline \multicolumn{10}{|l|}{$\begin{array}{l}\text { Archaeopspo- } \\
\text { rales }\end{array}$} \\
\hline \multicolumn{10}{|l|}{$\begin{array}{l}\text { Archae- } \\
\text { osporaceae }\end{array}$} \\
\hline $\begin{array}{c}\text { Archaeospora } \\
\text { europaea }\end{array}$ & A.eur1 & SAF113 & 11-FO107 & & $\begin{array}{l}\text { Uettlingen } \\
\text { BE }\end{array}$ & $\begin{array}{l}\text { Arable field } \\
\text { (winter } \\
\text { wheat) }\end{array}$ & 5.3 & 2011 & $\begin{array}{l}\text { Eutric Cam- } \\
\text { bisol }\end{array}$ \\
\hline $\begin{array}{c}\text { Archaeospora } \\
\text { europaea }\end{array}$ & A.eur2 & SAF114 & 11-FO126 & & Frick AG & $\begin{array}{l}\text { Arable field } \\
\text { (winter } \\
\text { wheat) }\end{array}$ & 7.6 & 2011 & $\begin{array}{l}\text { Vertic Cam- } \\
\text { bisol }\end{array}$ \\
\hline $\begin{array}{c}\text { Archaeospora } \\
\text { europaea }\end{array}$ & A.eur3 & SAF115 & 11-FO345 & & Rubigen BE & $\begin{array}{l}\text { Permanent } \\
\text { grassland }\end{array}$ & 5.8 & 2011 & $\begin{array}{l}\text { Eutric Cam- } \\
\text { bisol }\end{array}$ \\
\hline \multicolumn{10}{|l|}{$\begin{array}{l}\text { Paraglom- } \\
\text { erales }\end{array}$} \\
\hline \multicolumn{10}{|l|}{$\begin{array}{l}\text { Paraglomer- } \\
\text { aceae }\end{array}$} \\
\hline $\begin{array}{l}\text { Paraglomus } \\
\text { laccatum }\end{array}$ & P.lac1 & SAF56-1 & BEG21 & MN996958 & $\begin{array}{l}\text { Nenzlingen } \\
\text { BL }\end{array}$ & $\begin{array}{l}\text { Permanent } \\
\text { grassland }\end{array}$ & 7.7 & $1994^{5}$ & $\begin{array}{l}\text { Calcaric Lep- } \\
\text { tosol }\end{array}$ \\
\hline $\begin{array}{l}\text { Paraglomus } \\
\text { laccatum }\end{array}$ & P.lac2 & SAF56-2 & BEG21 & & $\begin{array}{l}\text { Nenzlingen } \\
\text { BL }\end{array}$ & $\begin{array}{l}\text { Permanent } \\
\text { grassland }\end{array}$ & 7.7 & $1994^{5}$ & $\begin{array}{l}\text { Calcaric Lep- } \\
\text { tosol }\end{array}$ \\
\hline
\end{tabular}

${ }^{1}$ According to IUSS Working Group WRB (2015)

${ }^{2}$ Taxa names are given based on nomenclatural rules. Here, we follow nomenclature after Oehl et al. (2011a, b), updated in Baltruschat et al. (2019) and Wijayawardene et al. (2020). The nomenclature of AMF is still partly under debate and some AMF are named differently by different authors (e.g., Krüger et al. 2012; Wijayawardene et al. 2020)

${ }^{3}$ Deposited at SAF 2008

${ }^{4}$ Propagated 2011/2012 for this study

${ }^{5}$ Pure culture in 1994; re-established in 2008

of nucleotide substitution was estimated using Topali 2.5 (Milne et al. 2004). Bayesian analysis (two runs over $3 \times 10^{6}$ generations with a sample frequency of 300 and a burn-in value of 25\%) was performed in MrBayes 3.1.2 (Ronquist and Huelsenbeck 2003), launched from Topali 2.5, using the GTR + G model. Our annotations follow the most recent systematics of the Glomeromycota (e.g., Baltruschat et al. 2019; Błaszkowski et al. 2018a, b; Corazon-Guivin et al. 2019; Oehl et al. 2019a; Silva et al. 2012; Tedersoo et al. 2018). Table 1 gives detailed information about sequence origin.

Isolates A.eur1, A.eur2, A.eur3, R.inv3, F.fra1, Do.com1, Cl.cla2, Cl.cla3, E.inf1, E.inf2, G.mar1, and G.mar2 were not included in the phylogenetic analyses because no DNA sequences could be obtained.

\section{Experiment setup}

To test the effect of the different AMF isolates on leek growth promotion and leek macronutrient uptake, a pot experiment was established in a glasshouse. In addition to the 44 AMF isolates (see Table 1), a non-mycorrhizal control was included. Each treatment was replicated six times, resulting in a total of 270 pots. As substrate, a mixture (1:1) of Loess subsoil which had been passed through a $5 \mathrm{~mm}$ sieve before autoclaving and mixing, and quartz sand was used. Soil and sand were separately sterilized by autoclaving $\left(121^{\circ} \mathrm{C}, 90 \mathrm{~min}\right)$ and afterwards mixed in equal proportion by weight. The chemical parameters of the substrate were as follows: $\mathrm{pH}\left(\mathrm{H}_{2} \mathrm{O}\right)=6.0, \mathrm{C}_{\text {org }}=1.4 \mathrm{~g} \mathrm{~kg}^{-1}$, 
$\mathrm{P}=8.3 \mathrm{mg} \mathrm{kg}^{-1}$, potassium $(\mathrm{K})=31.5 \mathrm{mg} \mathrm{kg}^{-1}$, $\mathrm{Ca}=910 \mathrm{mg} \mathrm{kg}^{-1}, \mathrm{Mg}=149 \mathrm{mg} \mathrm{kg}^{-1}$. Parameters were measured according to standard methods in the laboratory of F.M. Balzer, Wetter-Amönau, Germany. Phosphorus (P), potassium $(\mathrm{K})$, and magnesium $(\mathrm{Mg})$ were extracted with double lactate according to the method of Hoffmann (1991). In that method, plant available nutrients are extracted from soil with $0.02 \mathrm{M}$ Ca-lactate and $0.02 \mathrm{M}$ hydrochloric acid. Calcium (Ca) was extracted with $\mathrm{HCl}$ and $\mathrm{H}_{2} \mathrm{SO}_{4}$. Each pot was filled with $500 \mathrm{~g}$ of the substrate and watered to $100 \%$ water capacity. For the AMF treatments, $5 \mathrm{ml}$ inoculum was placed in a small, shallow hole in the center of each pot. The inoculum contained spores, root fragments, and substrate from the pot cultures of the AMF isolates. The control treatment received $5 \mathrm{ml}$ of the same substrate, in which no AMF symbiosis was established during AMF inoculum propagation. The inocula were covered with a thin layer of substrate and ten seeds of leek (Allium porrum L., variety 'Belton', F1 hybrid) were sown exactly above the inocula. Seedlings were thinned after emergence to four plants per pot. The plants were maintained in the glasshouse under natural light and average temperatures of $25^{\circ} \mathrm{C}$ by day and $18{ }^{\circ} \mathrm{C}$ at night. To ensure equal growth conditions, pots were completely randomized every 3 to 4 days. Plants were fertilized 3 weeks after emergence with $25 \mathrm{mg} \mathrm{N}, 10 \mathrm{mg}$ P, and $25 \mathrm{mg} \mathrm{K}$ per pot. Aboveground biomass of leek plants was harvested 8 weeks after emergence to avoid plants becoming pot-bound.

\section{Leek biomass and nutrient analyses}

Aboveground biomass was oven dried at $60{ }^{\circ} \mathrm{C}$ for $48 \mathrm{~h}$ and afterwards weighed. Before nutrient analyses, the dry matter was ground with a ball mill. Carbon and nitrogen concentrations of the shoots were determined with a CHNS-O Elemental Analyzer (Euro EA 3000, EuroVector SpA, Milan, Italy). For phosphorus, potassium, calcium, and magnesium, leek samples were dry ashed, solubilized in hydrochloric acid and subsequently measured with inductively coupled plasma optical emission spectrometry (Arcos FHS 16, Spectro Analytical Instruments GmbH, Kleve, Germany).

\section{AMF root colonization}

To measure AMF root colonization, all leek roots were washed, stained with a 5\% ink vinegar solution and mounted on microscope slides (Vierheilig et al. 1998). Hyphal, vesicular, and arbuscular root colonization were estimated according to the intersection method of McGonigle et al. (1990) using 100 intersections per sample.

\section{Statistical analyses}

The total root length colonized and the formation of vesicles and arbuscules were analyzed by using a beta regression model suitable for rates with the link function probit. For the effects of AMF isolates, species and genera on leek biomass one-way analyses of variance (ANOVA) were performed, each followed by Dunnett's test. To estimate the variance among species and of isolates within species, we used the restricted maximum likelihood (REML) method. When AMF family and order were used as explanatory variables, assumptions for an ANOVA-i.e., normal distribution of residuals and homogeneity of variances—could not be met; therefore, Kruskal-Wallis tests followed by Conover's manyto-one test were applied. For the response variables $\mathrm{P}, \mathrm{N}, \mathrm{K}$, $\mathrm{Ca}$, and $\mathrm{Mg}$ concentrations in plant tissues, MANOVA was not possible; therefore, again Kruskal-Wallis and Conover's many-to-one tests were run to compare AMF isolates. All significance levels were set at $p<0.05$. In every post hoc test (Dunnett's tests and Conover's many-to-one tests), $p$ values were adjusted according to the Benjamini-Hochberg procedure to correct for multiple testing (Benjamini and Hochberg 1995). The statistical analyses and graphing were carried out with the software R 4.0.5 (R Core Team 2021) using the packages stats, graphics, ggplot2 (Wickham 2016), betareg (Zeileis et al. 2021), PMCMRplus (Pohlert 2021), and lme4 (Bates et al. 2015).

\section{Results}

\section{AMF root colonization}

Total AMF root colonization differed significantly among the 44 AMF isolates tested (Fig. 1 and Table S1). With the exception of Dominikia compressa, leek plants inoculated with AMF isolates of the families Glomeraceae and Entrophosporaceae (both belonging to the order Glomerales) had higher percentages of AMF root colonization than isolates of other families (Fig. 1). Isolates of Oehlia, Rhizoglomus, and Claroideoglomus had the highest percentages of AMF root colonization (on average $88 \%$ for $O$. diaphana, $66 \%$ for $R$. irregulare, and around $55 \%$ for $R$. invermaium, Cl. candidum, and Cl. claroideum). Funneliformis, Septoglomus, and Entrophospora spp. showed medium to high AMF root colonization (41\% for F. mosseae, $34 \%$ for F. caledonius, 26\% for Septoglomus nigrum, and 20\% for Entrophospora infrequens), while Dominikia compressa had low colonization (4\%). From the Diversisporaceae, Di. celata and Di. epigaea had only 7\% and 3\% AMF root colonization, respectively. Of the Gigasporaceae, Gigaspora margarita had 21\%, and Cetraspora helvetica 4\% AMF root colonization. AMF 


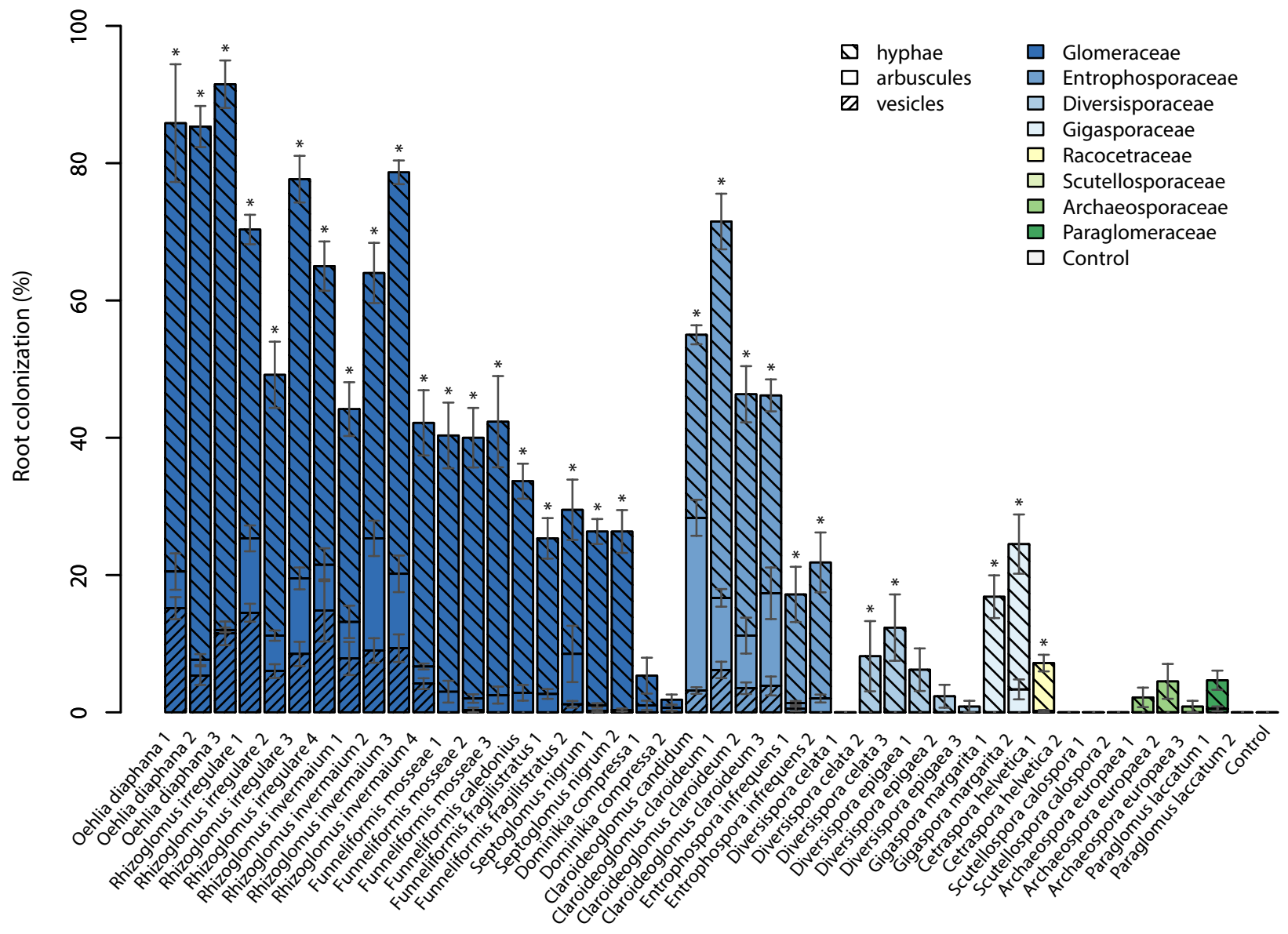

Fig. 1 Intraradical hyphae, arbuscules, and vesicles summed to total root length colonization of leek plants inoculated with 44 different isolates of arbuscular mycorrhizal fungi (AMF) and one non-mycorrhizal control. Data are reported as means $(n=6)$ and their standard errors. Significant total root length colonization is indicated by asterisks and was determined with a beta regression model $(p<0.05)$ isolates of the Archaeosporaceae and Paraglomeraceae had low AMF colonization (3\% for Archaeospora europaea and $2 \%$ for Paraglomus laccatum). No root colonization was observed in the control treatment without AMF added.

For some isolates, barely any colonization (isolate average of less than one percent) was detected, namely A.eur3, Ce.hel2, Di.cel1, Di.epi3, P.lac2, Sc.cal1, and Sc.cal2.

Linear regression analyses revealed no correlation between AMF spore densities of the AMF inocula and AMF root colonization $\left(r^{2}=0.03 ; p=0.24\right.$; Fig. $\left.\mathrm{S} 1\right)$.

In the leek roots, vesicle formation was highest in Oehlia, Rhizoglomus and Claroideoglomus species (11\% for $O$. diaphana, $12 \%$ for $R$. irregulare, $7 \%$ for $R$. invermaium, $5 \%$ for $\mathrm{Cl}$. claroideum, and $3 \%$ for $\mathrm{Cl}$. candidum). Vesicle formation was low to absent for other species of Glomeraceae and Entrophosporaceae, e.g., in Funneliformis, Septoglomus, Dominikia, and Entrophospora spp (Fig. 1). Vesicle formation was not observed for isolates of other AMF families.

Intraradical arbuscules were found in leek roots for all Glomeraceae and Entrophosporaceae species under study with the highest records for $C l$. candidum (25\%), Cl. claroideum (11\%), $R$. irregulare and $R$. invermaium (each 9\%), $F$. fragilistratus (5\%), and $O$. diaphana (4\%) and lowest in the Dominikia, Septoglomus, and Entrophospora isolates (c. 1\%). For almost all other isolates, virtually no arbuscules were detected, with the exception of one G. margarita isolate (3\%).

\section{Effects of AMF on plant biomass}

Inoculation with 44 different AMF isolates clearly affected the shoot biomass production of the leek plants. Inoculation with $20 \mathrm{AMF}$ isolates lead to significantly higher biomass than that of the controls (Fig. 2). None of the isolates had a statistically significant negative effect on leek shoot biomass. Overall, isolates with plant growth responses in similar magnitude belonged to the same taxonomic group (Fig. 2) and same phylogenetic clades, respectively (Fig. 3).

Results of restricted maximum likelihood analyses showed a highly significant effect of AMF species on leek 


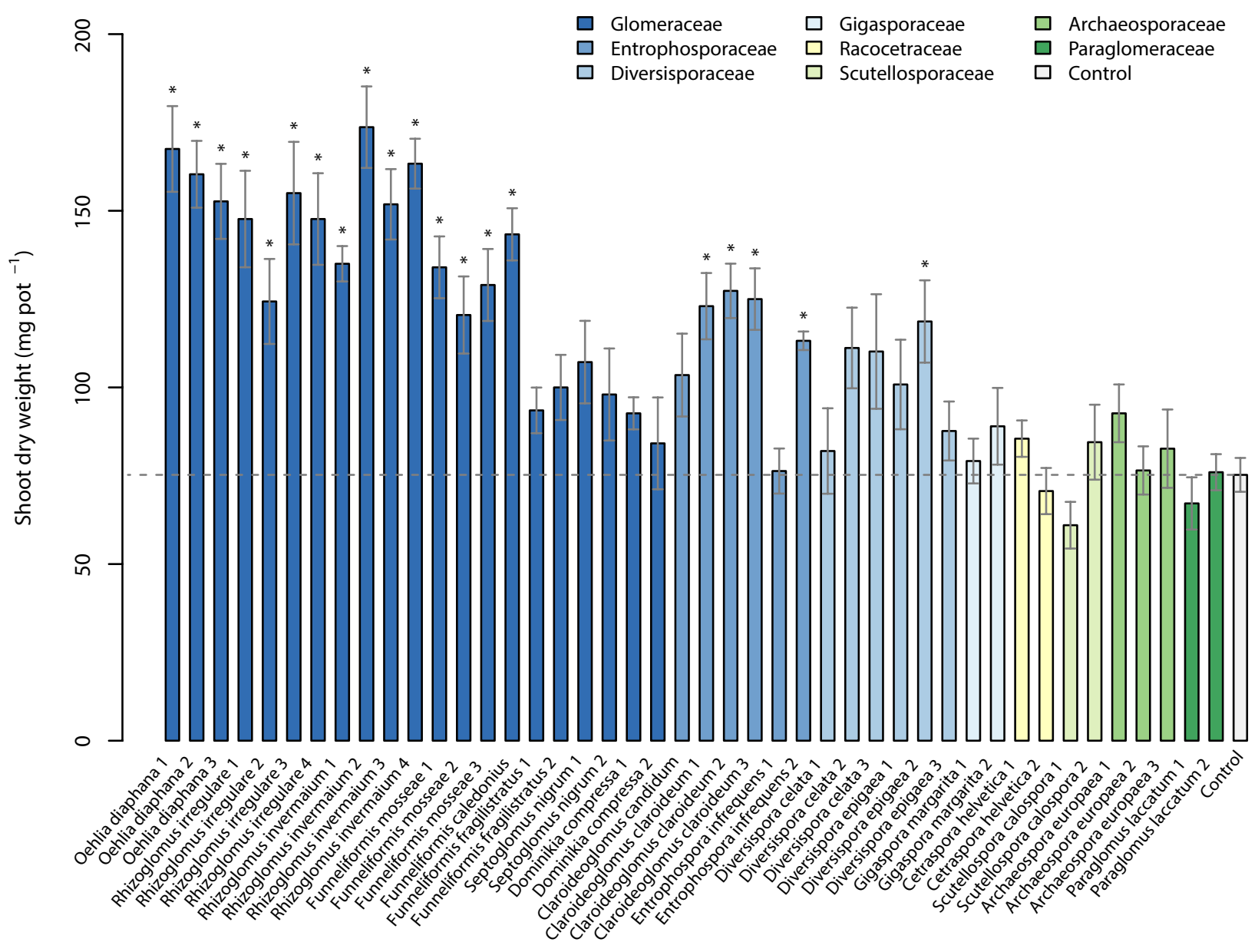

Fig. 2 Aboveground biomass of leek inoculated with 44 different isolates of arbuscular mycorrhizal fungi (AMF) and one non-mycorrhizal control. Data are reported as means $(n=6)$ and their standard errors. Significant differences between AMF isolates and the control treatment (bar and dashed horizontal line) are indicated by asterisks and were determined with Dunnett's test $(p<0.05)$ after a one-way ANOVA biomass, but no significant effect of isolates within species (Table S2).

For species, the highest biomass production was observed for Oehlia and Rhizoglomus species (Fig. S2). For instance, the biomass of plants inoculated with $O$. diaphana, $R$. invermaium, and $R$. irregulare increased by $112 \%, 107 \%$, and $91 \%$, respectively, compared to the nonmycorrhizal controls. Also, after inoculation with $\mathrm{F}$. caledonius (+90\%), F. mosseae $(+70 \%)$, and Cl. claroideum $(+67 \%)$, leek plants produced significantly more biomass than the non-mycorrhizal controls. For other isolates from the families Glomeraceae and Entrophosporaceae (e.g., Dominikia compressa, Septoglomus nigrum, Entrophospora infrequens, and $\mathrm{Cl}$. candidum); however, no significant differences versus the non-mycorrhizal control plants were detected. Although for three of the Diversisporales isolates, fairly high plant growth promotion was observed, these effects $(+47$ to $+57 \%)$ were not significant. Members of Gigasporales, Archaeosporales, and Paraglomerales showed no significant effect on leek biomass.

Significant effects were also found at the level of AMF genera (Fig. S3).

Multiple comparisons between AMF families showed that Glomeraceae had a significantly higher leek biomass than all other AMF families (+97 to $+17 \%)$ and than the control treatment (+76\%; Fig. S4). Entrophosporaceae and Diversisporaceae also differed significantly from the control treatment $(+50 \%$ and $+46 \%$; Fig. S4).

Leek biomass was positively correlated with root length colonization $\left(r^{2}=0.45 ; p<0.05\right.$; Fig. 4$)$.

\section{Effects of AMF on nutrient concentrations in leek shoots}

Phosphorus concentrations of the leek shoots were substantially affected by AMF inoculation. The effects of the AMF 


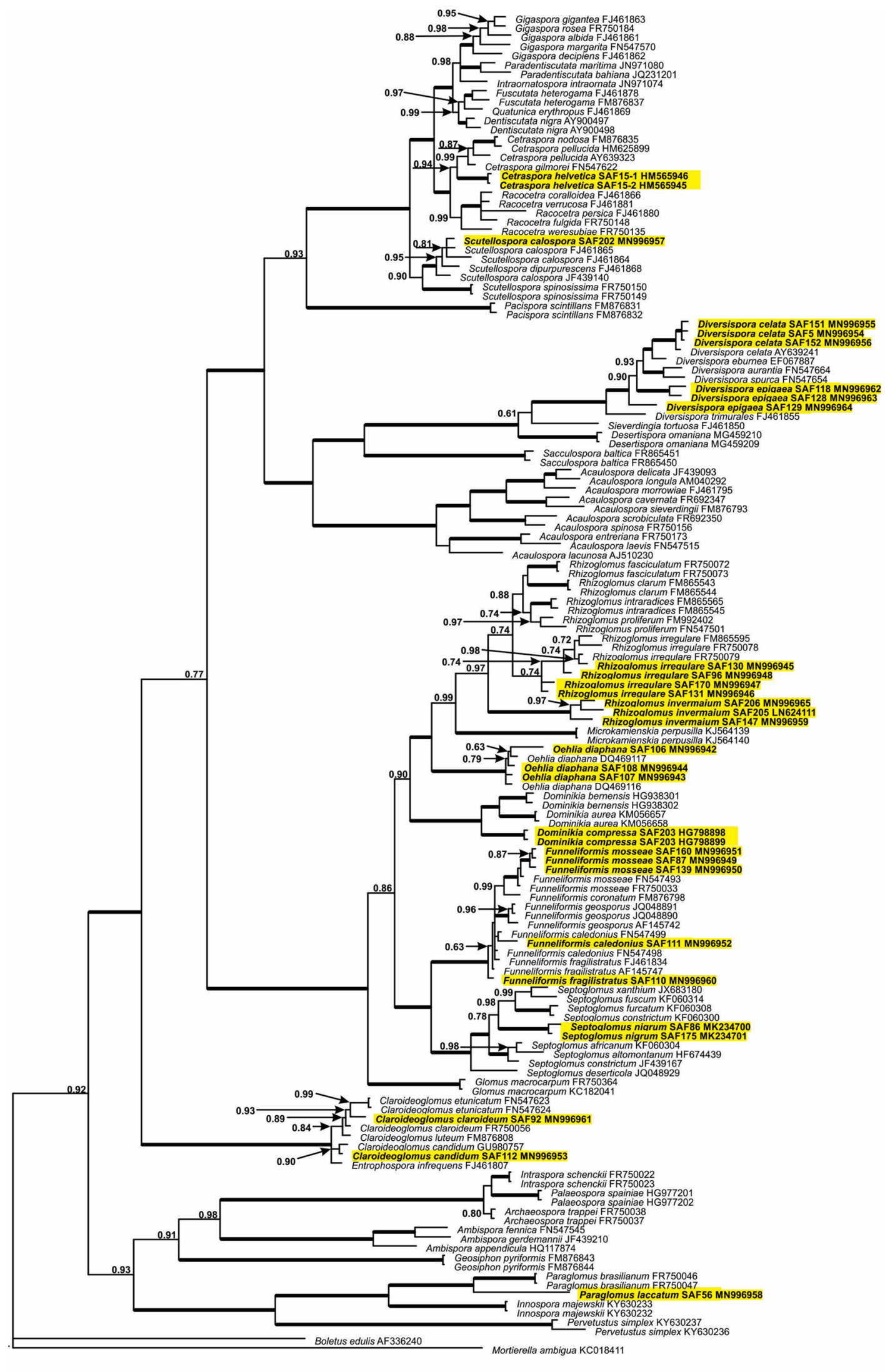

0.1 
4Fig. 3 Phylogenetic tree of arbuscular mycorrhizal fungi (AMF) obtained by analysis of partial LSU rDNA sequences. The tree is based on the Bayesian Inference method. Sequences are labeled with their database accession numbers. Only support values of at least $60 \%$ are shown. Thick branches represent clades with $100 \%$ support. The tree was rooted by Boletus edulis and Mortierella ambigua. Isolates which are used for the inoculation experiment are marked in yellow (twelve isolates that could not be sequenced are missing)

isolates on total $\mathrm{P}$ contents in leek plants were even stronger than those observed for shoot biomass. The phosphorus concentration in leek shoots was highest after inoculation with isolates of the species $O$. diaphana ( $+155 \%$ in average), $R$. invermaium ( $+166 \%$ ), and $R$. irregulare (+156\%; Fig. 5a). Funneliformis isolates led to elevated P concentrations; but these effects were not always significant. This also was found for Claroideoglomus and Diversispora isolates. Two species led to significantly increased $\mathrm{P}$ concentrations, namely $F$. mosseae and $\mathrm{Cl}$. claroideum. There was no enhancement or a slight reduction of shoot $\mathrm{P}$ concentration after inoculation with Do. compressa, Ce. helvetica, and Paraglomus laccatum (Fig. 5a).

Similar to phosphorus assimilation, shoot nitrogen concentration was affected by AMF inoculation. The most effective isolates were F.mos3, F.cal, and F.mos1. There was no significant increase in shoot $\mathrm{N}$ concentration for a few Glomerales and Diversisporales isolates as well as for Ce.hel1 and P.lac1 (Fig. 5b). Taking the averages of the species, the shoot $\mathrm{N}$ concentration was highest after inoculation with $F$. caledonius ( $+53 \%$ when compared to the control treatment), followed by values obtained after inoculation with $F$. mosseae $(+50 \%)$, O. diaphana $(+43 \%)$, R. irregulare $(+40 \%)$, Cl. claroideum $(+37 \%)$, and $R$. invermaium $(+33 \%)$.

$\mathrm{N}: \mathrm{P}$ ratios of dry leek biomass ranged from $11.6 \mathrm{mgN} /$ $\mathrm{mgP}$ (R.inv3) to 47.9 (Sc.cal1) $\mathrm{mgN} / \mathrm{mgP}$. Compared to the control treatment - which had a N:P ratio of $24.7-\mathrm{N}: \mathrm{P}$ ratios were significantly lower than the controls for all isolates of the genera Oehlia and Rhizoglomus as well as for the two isolates Cl.cla1 and E.inf2. Some isolates showed higher $\mathrm{N}: \mathrm{P}$ ratios than controls, but with a high standard deviation of the means, effects were not significant (Fig. S5).

For some isolates - namely Oehlia, Rhizoglomus, Claroideoglomus, and Diversispora species-potassium concentration in leek aboveground biomass was slightly enhanced. In contrast, Funneliformis and Paraglomus isolates tended to result in a lower K concentration than that of the controls. However, these effects were not statistically significant (Fig. S6). Also, for magnesium concentration, there was no effect of $\mathrm{AMF}$ inoculation (Fig. S7). The majority of AMF isolates and species resulted in a lower calcium concentration of leek plants compared to the nonmycorrhizal controls (Fig. S8). The lowest Ca concentrations were found for all isolates of Funneliformis and Septoglomus with a decrease between 30\% (Fu.mos1) and 36\% (Fu.mos3).
Fig. 4 Linear regression between leek shoot dry weight and AMF root length colonization across all isolates $\left(r^{2}=0.45 ; p<0.05\right)$ with $95 \%$ prediction (dashed lines) and confidence intervals (dash and dot lines)

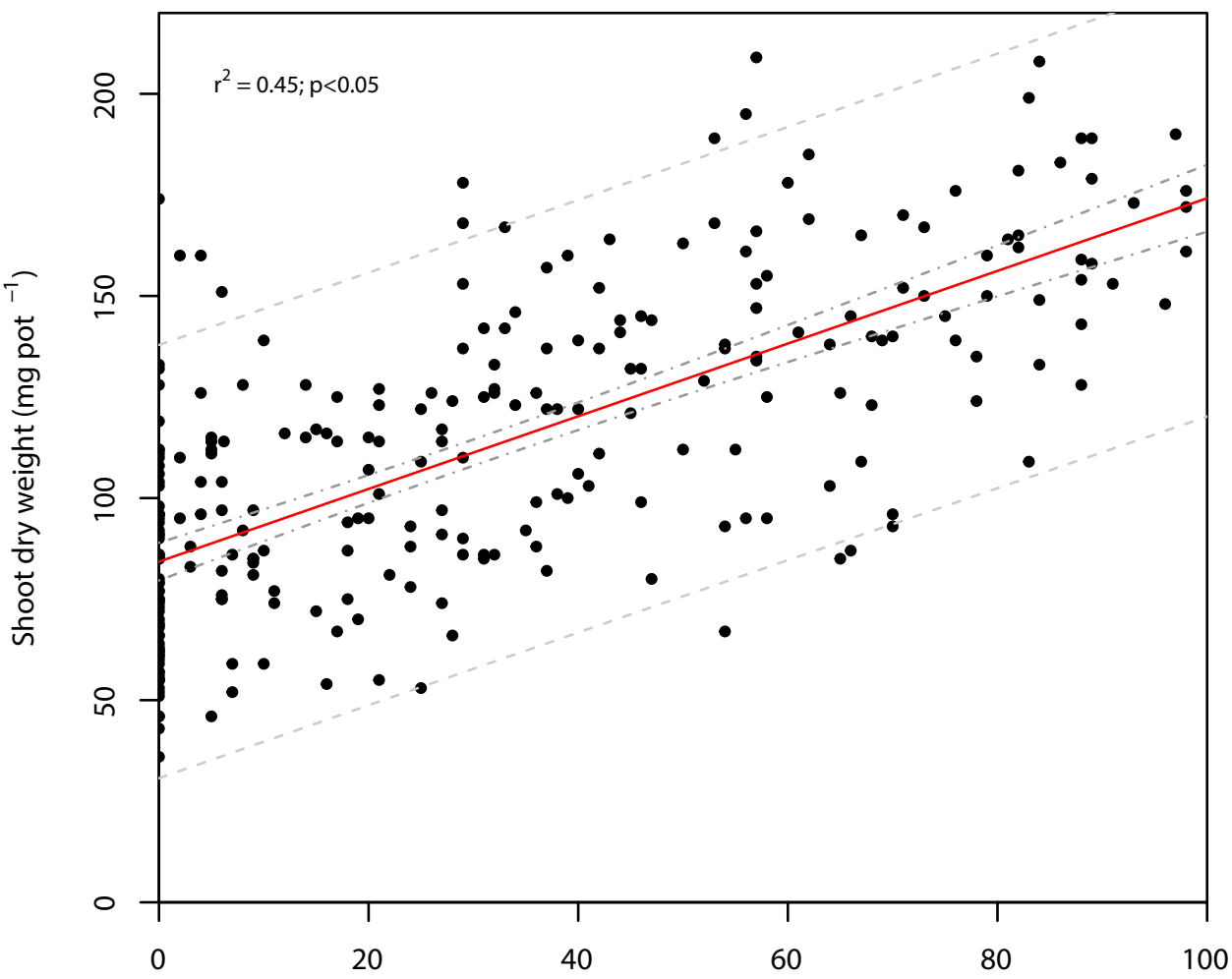

Root length colonization (\%) 

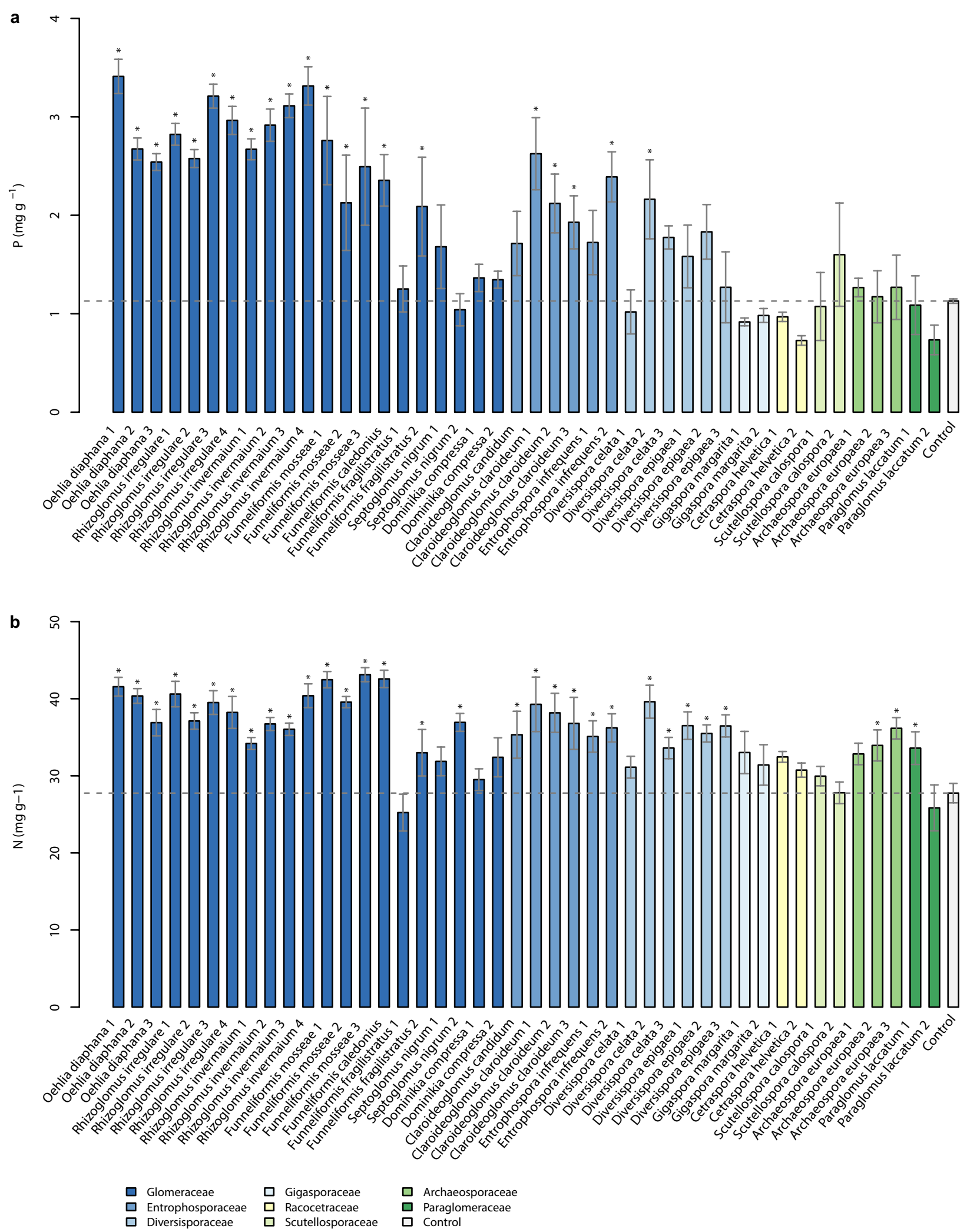

Fig. 5 Phosphorus a and nitrogen $\mathbf{b}$ concentrations in above ground leek biomass inoculated with 44 different AMF isolates and one nonmycorrhizal control. Data are reported as means $(n=6)$ and their standard errors. Significant differences between AMF isolates and the control treatment (bar and dashed horizontal line) are determined with Conover's many-to-one test $(p<0.05)$ after the non-parametric Kruskal-Wallis test and are indicated by asterisks 


\section{Discussion}

This study demonstrates that different AMF taxa differ in their effects on plant growth. Especially ancient AMF lineages were least beneficial in terms of stimulating plant growth. The intraspecific differences among isolates of the same AMF species were small compared to those among AMF species. AMF species, genera and families displayed different performances in root colonization. Furthermore, we showed that taxonomic and phylogenetic characterization of AMF isolates based on morphology and molecular analysis were largely congruent. To obtain the best classification, it is recommended to apply both methods in combination (Oehl et al. 2011a).

Almost all AMF isolates that were tested showed a positive effect on leek biomass versus the non-mycorrhizal control. This was expected, because leek is known to be responsive to mycorrhizal fungi (e.g., Plenchette et al. 1982; Jansa et al. 2008; Karaca 2012; Kohler-Milleret et al. 2013). Some AMF isolates, however, resulted in higher growth promotion than other isolates. Such differences among AMF species in their ability to promote plant growth or nutrient acquisition have been observed multiple times (Jansa et al. 2008; Klironomos 2003; Pringle and Bever 2008; Tchabi et al. 2010; Thonar et al. 2011). Also, in the present study, different AMF species affected leek growth and nutrient uptake differently depending on the clade to which they belong. Oehlia and Rhizoglomus spp. provided the highest benefit to leek growth, followed by species belonging to Funneliformis, Claroideoglomus, and Diversispora, while Paraglomerales, Archaeosporales, and Gigasporales did not significantly affect leek growth.

From an evolutionary point of view, Paraglomerales and Archaeosporales are the most ancient AMF. These fungal clades date back about 460 million years, while members from the Glomerales and Gigasporales evolved more recently (Morton and Redecker 2001; Redecker et al. 2000a; Silva et al. 2012). A study by Koch et al. (2017) observed conservatism in fungal traits but did not find effects of fungal phylogeny on plant growth stimulation. In our study, however, species that diverged early in evolutionary history (e.g., Paraglomus laccatum and Archaeospora sp.; Redecker et al. 2000b) were less beneficial in stimulating plant biomass than phylogenetically younger taxa (especially Glomeraceae species). Different effects of ancient and more recently evolved AMF on plant biomass might be due to niche differentiation-e.g., members of the Paraglomeraceae have reduced root colonization and appear to be build extensive extra-radical mycelium in the soil (Hempel et al. 2007). Alternatively, the different effects might be due to differences in terms of carbon and nutrient exchange between plants and particular AMF taxa-e.g., ancient AMF appear to provide only limited amounts of nutrients to plants. As we did not assess extraradical mycelium or carbon exchange, we only can hypothesize that these two factors may have caused differences in leek growth.

In a meta-analysis by Hoeksema et al. (2018), fungal phylogeny and fungal identity (genus) did not explain plant responses to AMF. Besides context dependency, this could be due to few studies actually having tested the response of plants to ancient AMF and very few data entries for ancient AMF taxa being included in the database making it difficult to test this. Additionally, our study was unbalanced in that only a few isolates of Paraglomus and Archaeospora were tested, making these ancient AMF taxa underrepresented. Nevertheless, in this study, we analyzed clearly more "ancient" AMF taxa than did preceding works. It also should be taken into account that our study reflects the natural distribution of AMF genera, as the current classification of AMF accepts 20 genera in the order Glomerales, while there are only ten in Diversisporales, eleven in Gigasporales, five in Archaeosporales and three in Paraglomerales (Wijayawardene et al. 2020). This indicates that there simply are fewer ancient species available. Sieverding and Howeler (1985) and Howeler et al. (1987) evaluated a range of AMF species, including the ancient species Paraglomus occultum and found varying effects of this species, ranging from no effect to significant plant growth promotion. Powell et al. (2009) examined 27 AMF species and assessed with compiled data from three different glasshouse studies whether AMF phylogeny is related to functional traits of AMF (root and soil colonization, plant growth benefit). They observed that some traits, like root and soil colonization or host benefits, may be phylogenetically conserved with which our study agrees.

Hart and Reader (2002a) showed that in two plant species (Plantago lanceolata and Poa аппиа) Glomeraceae provided the greatest and Acaulosporaceae the least plant growth promotion. They related this to the large internal mycelium of Glomeraceae. Differences in carbon demand (Elbon and Whalen 2015) also are considered. Tchabi et al. (2010) showed that also several Acaulospora species derived from tropical areas, however, might provide significant plant growth promotion under tropical conditions, and that species such as A. scrobiculata, A. minuta, and A. spinosissima, might also be able to elaborate substantial internal mycelium (Tchabi et al. 2010; Oehl et al. 2014a, b).

Because our experiment was run only for 8 weeks from plant emergence, life cycles of the symbionts may play a significant role in the positive effects on plant growth. Life cycles of Rhizoglomus, Funneliformis, Oehlia, and Claroideoglomus species are faster than those of Dominikia and Septoglomus species and Gigasporales species in the temperate zones (Oehl et al. 2009). These observations do not explain the ineffectiveness of the Archaeospora and 
Paraglomus isolates, which have similarly fast life cycles to Oehlia diaphana, Funneliformis mosseae, Rhizoglomus irregulare, Claroideoglomus claroideum, and $\mathrm{Cl}$. etunicatum (Oehl et al. 2005, 2009). Nevertheless, there are differences in colonization rate, i.e., the time from inoculation to the first colonization of roots. In a screening of 21 AMF isolates by Hart and Reader (2002b), species of Glomeraceae were found to be the fastest in root colonization with an initial root colonization from 1 to 3 weeks after inoculation depending on the species, while some members Gigasporaceae and Acaulosporaceae needed 6 to 8 weeks. This may be one reason-among others - that in our experiment, inoculation with isolates of Glomeraceae resulted in highest leek biomass gain.

Another aspect is the cultivation duration of isolates. Although all AMF isolates were propagated under same conditions, some isolates-namely Di.cel1, all isolates of Gigasporales and Paraglomerales-were propagated for a longer time than the others. Bentivenga et al. (1997) showed that propagation can change characteristics such as spore size and color in a few generations. We cannot exclude that interaction traits of AMF with plants changed over the time in pot culture.

Some studies found functional variation within AMF species (e.g., de Novais et al. 2014; Koch et al. 2006; Munkvold et al. 2004). In our study, however, the variation among isolates of the same species was less pronounced than that among species. This probably is because the inocula of different isolates of the same species had similar spore densities, identical ages and were obtained in similar conditions. Therefore, they probably were of very similar quality which could explain why intra-specific variability was low in our study.

Overall, AMF isolates which increased leek biomass enhanced shoot $\mathrm{P}$ and $\mathrm{N}$ concentrations as well. Previous studies also showed the effect of AMF accumulating P and/ or $\mathrm{N}$ in plant biomass for leek (Fusconi et al. 2005; Hart and Forsythe 2012) and for other plant species such as tomato (Ortas et al. 2013), Medicago truncatula (Burleigh et al. 2002), M. sativa (Avio et al. 2006), and apple (Cavallazzi et al. 2007). Lendenmann et al. (2011) suggested that differences in $\mathrm{P}$ acquisition between $R$. intraradices and $\mathrm{Cl}$. claroideum are due to differences in mycelium length density and in $\mathrm{P}$ transporters. In addition, there also is evidence that Gigasporaceae can retain $\mathrm{P}$ in their hyphae before it is transported to the host plant (Jakobsen et al. 1992; Dodd et al. 2000; Solaiman and Saito 2001). Even if there is no growth response by an AMF inoculated plant, $\mathrm{P}$ uptake via the mycorrhizal pathway can occur; hence, the fungus contributes to the plant's nutrition (Smith et al. 2004). Thus, under experimental conditions with $\mathrm{P}$ as the growth-limiting factor, optimal plant growth promotion can be attained by
AMF that provide the greatest $\mathrm{P}$ transfer to the host plant with the least demand for carbon (Burleigh et al. 2002).

Güsewell (2004) stated that plants with N:P ratios $<10$ often are $\mathrm{N}$-limited in biomass production, while plants with $\mathrm{N}: \mathrm{P}$ ratios $>20$ instead are limited by phosphorous. More than half of the AMF isolates of the present study resulted in a $\mathrm{N}: \mathrm{P}$ ratio over 20 , indicating that those treatments probably were P limited. There was no N:P ratio below 10 , so we suppose that none of the leek plants lacked N. Those isolates that led to low $\mathrm{N}: \mathrm{P}$ ratios also are those that resulted in elevated plant biomass. Therefore, we conclude that growth promotion by those isolates was most likely because they improved P supply.

While the acquisition of most nutrients was positively influenced ( $\mathrm{N}$ and $\mathrm{P}$ ) or not affected $(\mathrm{K}$ and $\mathrm{Mg}$ ) by $\mathrm{AMF}$, $\mathrm{Ca}$ concentrations were notably low in the control treatment. This also was observed by Baslam et al. (2011). They attributed this to a dilution effect because inoculated plants showed elevated biomass. In our case, plants with no growth response also had low Ca concentrations; therefore, we think this does not apply for our case. As we did not assess $\mathrm{Ca}$ concentrations in roots, we cannot identify if uptake from the soil via roots or via the AMF pathway is reduced, or if $\mathrm{Ca}$ is retained in the roots of AMF inoculated leek plants.

In our study, root colonization was positively correlated with biomass gain with species of Archaeosporaceae and Paraglomeraceae having the lowest colonization and plant growth responses. As expected, vesicle formation by Gigasporales, Archaeosporales, and Paraglomerales isolates was not observed. Two Diversisporales species also formed no vesicles in contrast to earlier reports (Oehl et al. $2011 \mathrm{~b}$; Błaszkowski 2012; Błaszkowski et al. 2019). It must be considered that hyphae, arbuscules, and vesicles of Archaeosporaceae and Paraglomeraceae barely stain in trypan blue or ink (Oehl et al. 2011a, b) and therefore might have been underestimated. For sparsely colonizing isolates, it also is possible that the establishment of the symbiosis was not successful. Previous studies show divergent results. Intense fungal root colonization often is not associated with improved plant growth (Burleigh et al. 2002; Mensah 2015; Munkvold et al. 2004; Smith et al. 2004; Tchabi et al. 2010). Avio et al. (2006) showed a positive correlation between these two factors, however, and Treseder (2013) revealed in a metaanalysis that plant growth generally tends to improve with increased root colonization.

Early plants did not have extensive root systems and therefore they likely were limited in their uptake of mineral nutrients (Fitter 2005). As plants developed extensive, complex root systems, AMF co-evolved. Hence, plants provided an important habitat for AMF which became dependent on their host plants, while plants became more efficient in mycorrhiza formation (Brundrett 2002). Thus, the reduced 
ability of ancient AMF to promote nutrient uptake and plant growth might be related to limited root colonization.

There might be other factors than taxonomic and phylogenetic traits of AMF that determine the beneficial effects of AMF species on leek growth. Gigasporales species are known to be frequent in warm climates and thus may be inefficient for leek in cool/temperate climates than better adapted clades such as Funneliformis, Rhizoglomus or Oehlia (Oehl et al. 2017). From our results, we conclude that taxonomic relatedness of AMF species likely can be used to make predictions about functional relationships in the symbiosis between plants and AMF. In our study, however, only a few ancient isolates like Paraglomus laccatum were available and our dataset was biased towards lineages of Glomeraceae. Therefore, these results may not provide a complete picture. We highly recommend integration of additional ancient species in future tests.

Supplementary Information The online version contains supplementary material available at https://doi.org/10.1007/s00572-021-01042-5.

Acknowledgements We would like to thank the two anonymous reviewers and the editorial board for their helpful comments.

Author contributions F.O., V.S., and M.H. designed the experiment. V.S., J.P., C.A.A., I.S.C., B.S., and F.O. carried out the laboratory work; V.S. and G.S. analyzed the data and prepared the figures. V.S. with help from M.H. drafted the manuscript. All authors edited the manuscript and gave final approval for publication.

Funding Open Access funding provided by Agroscope. This work was supported by the Swiss National Science Foundation SNSF, grant 130764 ("Antagonism in the mycorrhizal symbiosis—a search for mechanisms").

Availability of data and material DNA sequences are deposited in the NCBI GenBank (www.ncbi.nlm.nih.gov/genbank/). Other data generated during the current study are available from the corresponding author

\section{Declarations}

Conflict of interest The authors declare no competing interests.

Open Access This article is licensed under a Creative Commons Attribution 4.0 International License, which permits use, sharing, adaptation, distribution and reproduction in any medium or format, as long as you give appropriate credit to the original author(s) and the source, provide a link to the Creative Commons licence, and indicate if changes were made. The images or other third party material in this article are included in the article's Creative Commons licence, unless indicated otherwise in a credit line to the material. If material is not included in the article's Creative Commons licence and your intended use is not permitted by statutory regulation or exceeds the permitted use, you will need to obtain permission directly from the copyright holder. To view a copy of this licence, visit http://creativecommons.org/licenses/by/4.0/.

\section{References}

Avio L, Pellegrino E, Bonari E, Giovannetti M (2006) Functional diversity of arbuscular mycorrhizal fungal isolates in relation to extraradical mycelial networks. New Phytol 172:347-357. https:// doi.org/10.1111/j.1469-8137.2006.01839.x

Baltruschat H, Santos VM, Silva DKA, Schellenberg I, Deubel A, Sieverding E, Oehl F (2019) Unexpectedly high diversity of arbuscular mycorrhizal fungi in fertile Chernozem croplands in Central Europe. CATENA 182:104135. https://doi.org/10.1016/j. catena.2019.104135

Banerjee S, Walder F, Büchi L, Meyer M, Held AY, Gattinger A, Keller T, Charles R, van der Heijden MGA (2019) Agricultural intensification reduces microbial network complexity and the abundance of keystone taxa in roots. ISME J 13:1722-1736. https://doi.org/10.1038/s41396-019-0383-2

Baslam M, Garmendia I, Goicoechea N (2011) Arbuscular mycorrhizal fungi (AMF) improved growth and nutritional quality of greenhouse-grown lettuce. J Agr Food Chem 59(10):55045515. https://doi.org/10.1021/jf200501c

Bates D, Mächler M, Bolker B, Walker S (2015) Fitting linear mixedeffect models using lme4. J Stat Softw 67(1):1-48. https://doi. org/10.18637/jss.v067.i01

Bender SF, Wagg C, van der Heijden MGA (2016) An underground revolution: biodiversity and soil ecological engineering for agricultural sustainability. Trends Ecol Evol 31:440-452. https://doi.org/10.1016/j.tree.2016.02.016

Benjamini Y, Hochberg Y (1995) Controlling the false discovery rate: a practical and powerful approach to multiple testing. J R Stat Soc Series B Stat Methodol 57(1):289-300. https://doi. org/10.1111/j.2517-6161.1995.tb02031.x

Bentivenga SP, Bever JD, Morton JB (1997) Genetic variation of morphological characters within a single isolate of the endomycorrhizal fungus Glomus clarum (Glomaceae). Am J Bot 84(9):1211-1216. https://doi.org/10.2307/2446044

Błaszkowski J (2012) Glomeromycota. W Szafer Institute of Botany, Polish Academy of Sciences

Błaszkowski J, Chwat G, Góralska A, Ryszka P, Kovács GM (2015) Two new genera Dominikia and Kamienskia and D disticha sp nov in Glomeromycota. Nova Hedwigia 100:225-238. https:// doi.org/10.1127/nova_hedwigia/2014/0216

Błaszkowski J, Niezgoda P, Goto BT, Kozłowska A (2018a) Halonatospora gen nov with $\mathrm{H}$ pansihalos comb nov and Glomus bareae sp nov (Glomeromycota Glomeraceae). Botany 96:737748. https://doi.org/10.1139/cjb-2018-0107

Błaszkowski J, Kozłowska A, Niezgoda P, Goto BT, Dalpé Y (2018b) A new genus Oehlia with Oehlia diaphana comb nov and an emended description of Rhizoglomus vesiculiferum comb nov in the Glomeromycotina. Nova Hedwigia 107:501-518. https:// doi.org/10.1127/nova_hedwigia/2018/0488

Błaszkowski J, Niezgoda P, Paiva JN, Silva KJG, Theodoro RC, Jobim K, Orfanoudakis M, Goto BT (2019) Sieverdingia gen nov $\mathrm{S}$ tortuosa comb nov and Diversispora peloponnesiaca sp nov in the Diversisporaceae (Glomeromycota). Mycol Prog 18:1363-1382. https://doi.org/10.1007/s11557-019-01534-x

Brundrett M, Melville L, Peterson L (1994) Practical Methods in Mycorrhiza Research: Based on a Workshop Organized in Conjunction with the Ninth North American Conference on Mycorrhizae University of Guelph Guelph Ontario Canada. Mycologue Publications, British Columbia

Brundrett M (2002) Coevolution of roots and mycorrhizas of land plants. New Phytol 154:275-304. https://doi.org/10.1046/j. 1469-8137.2002.00397.x

Burleigh S, Cavagnaro T, Jakobsen I (2002) Functional diversity of arbuscular mycorrhizas extends to the expression of plant 
genes involved in P nutrition. J Exp Bot 53:1593-1601. https:// doi.org/10.1093/jxb/erf013

Cabello M (1999) Effectiveness of indigenous arbuscular mycorrhizal fungi (AMF) isolated from hydrocarbon polluted soils. J Basic Microbiol 39:89-95

Cavallazzi J, Filho O, Stürmer S, Rygiewicz P, de Mendonca M (2007) Screening and selecting arbuscular mycorrhizal fungi for inoculating micropropagated apple rootstocks in acid soils. Plant Cell Tissue Organ Cult 90:117-129. https://doi.org/10. 1007/s11240-006-9163-6

Corazon-Guivin MA, Cerna-Mendoza A, Guerrero-Abad JC, VallejosTapullima A, Carballar-Hernández S, Silva GA, Oehl F (2019) Nanoglomus plukenetiae, a new fungus from Peru, and a key to small-spored Glomeraceae species including three new genera in the "Dominikia complex/clades." Mycol Prog 18:1395-1409. https://doi.org/10.1007/s11557-019-01522-1

Davison J, Moora M, Öpik M, Adholeya A, Ainsaar L, Bâ A, Burla S, Diedhiou AG, Hiiesalu I, Jairus T, Johnson NC, Kane A, Koorem K, Kochar M, Ndiaye C, Pärtel M, Reier Ü, Saks Ü, Singh R, Vasar M, Zobel M (2015) Global assessment of arbuscular mycorrhizal fungus diversity reveals very low endemism. Sci 349:970-973. https://doi.org/10.1126/science.aab1161

de Novais C, Borges W, Jesus E, Saggin O, Siqueira J (2014) Inter- and intraspecific functional variability of tropical arbuscular mycorrhizal fungi isolates colonizing corn plants. Appl Soil Ecol 76:78-86. https://doi.org/10.1016/j.apsoil.2013.12.010

Dodd J, Boddington C, Rodriguez A, Gonzalez-Chavez C, Mansur I (2000) Mycelium of Arbuscular Mycorrhizal fungi (AMF) from different genera: form function and detection. Plant Soil 226:131-151. https://doi.org/10.1023/A:1026574828169

Elbon A, Whalen J (2015) Phosphorus supply to vegetable crops from arbuscular mycorrhizal fungi: a review. Biol Agric Hortic 31:7390. https://doi.org/10.1080/01448765.2014.966147

Estrada B, Aroca R, Maathuis F, Barea J, Ruiz-Lozano J (2013) Arbuscular mycorrhizal fungi native from a Mediterranean saline area enhance maize tolerance to salinity through improved ion homeostasis. Plant Cell Environ 36:1771-1782. https://doi.org/10.1111/ pce. 12082

Evelin H, Devi TS, Gupta S, Kapoor R (2019) Mitigation of salinity stress in plants by arbuscular mycorrhizal symbiosis: current understanding and new challenges. Front Plant Sci 10:470. https://doi.org/10.3389/fpls.2019.00470

Feddermann N, Finlay R, Boller T, Elfstrand M (2010) Functional diversity in arbuscular mycorrhiza - the role of gene expression phosphorous nutrition and symbiotic efficiency. Fungal Ecol 3:1-8. https://doi.org/10.1016/j.funeco.2009.07.003

Fester T, Sawers R (2011) Progress and challenges in agricultural applications of arbuscular mycorrhizal fungi. Crit Rev Plant Sci 30:459-470. https://doi.org/10.1080/07352689.2011.605741

Fitter A (2005) Darkness visible: reflections on underground ecology. J Ecol 93:231-243. https://doi.org/10.1111/j.0022-0477.2005. 00990.X

Fusconi A, Lingua G, Trotta A, Berta G (2005) Effects of arbuscular mycorrhizal colonization and phosphorus application on nuclear ploidy in Allium porrum plants. Mycorrhiza 15:313-321. https:// doi.org/10.1007/s00572-004-0338-x

Güsewell S (2004) N: P ratios in terrestrial plants: variation and functional significance. New Phytol 164(2):243-266

Hart M, Forsythe J (2012) Using arbuscular mycorrhizal fungi to improve the nutrient quality of crops; nutritional benefits in addition to phosphorus. Sci Hortic 148:206-214. https://doi.org/10. 1016/j.scienta.2012.09.018

Hart MM, Reader RJ (2002a) Host plant benefit from association with arbuscular mycorrhizal fungi: variation due to differences in size of mycelium. Biol Fertil Soils 36:357-366. https://doi.org/10. 1007/s00374-002-0539-4
Hart MM, Reader RJ (2002b) Taxonomic basis for variation in the colonization strategy of arbuscular mycorrhizal fungi. New Phytol 153(2):335-344. https://doi.org/10.1046/j.0028-646X.2001.00312.x

Hempel S, Renker C, Buscot F (2007) Differences in the species composition of arbuscular mycorrhizal fungi in spore root and soil communities in a grassland ecosystem. Environ Microbiol 9:1930-1938. https://doi.org/10.1111/j.1462-2920.2007.01309.x

Hildebrandt U, Regvar M, Bothe H (2007) Arbuscular mycorrhiza and heavy metal tolerance. Phytochem 68:139-146

Hoeksema JD, Bever JD, Chakraborty S, Chaudhary VB, Gardes M, Gehring CA, Hart MM, Housworth EA, Kaonongbua W, Klironomos JN et al (2018) Evolutionary history of plant hosts and fungal symbionts predicts the strength of mycorrhizal mutualism. Commun Biol 1:116. https://doi.org/10.1038/s42003-018-0120-9

Hoffmann G (1991) VDLUFA Methodenbuch Band I: Die Untersuchung von Böden. VDLUFA-Verlag, Darmstadt

Howeler RH, Sieverding E, Saif S (1987) Practical aspects of mycorrhizal technology in some tropical crops and pastures. Plant Soil 100:249-283. https://doi.org/10.1007/978-94-009-3627-0_18

IUSS Working Group WRB (2015) World Reference Base for Soil Resources 2014 update 2015. International soil classification system for naming soils and creating legends for soil maps. World Soil Resources Reports No 106 FAO Rome

Jakobsen I, Abbott L, Robson A (1992) External hyphae of vesiculararbuscular mycorrhizal fungi associated with Trifolium subterraneum L. 2. Hyphal transport of ${ }^{32} \mathrm{P}$ over definded distances. New Phytol 120:509-516. https://doi.org/10.1111/j.1469-8137. 1992.tb01800.x

Jansa J, Smith FA, Smith SE (2008) Are there benefits of simultaneous root colonization by different arbuscular mycorrhizal fungi? New Phytol 177:779-789. https://doi.org/10.1111/j.1469-8137. 2007.02294.X

Jia Y, van der Heijden MGA, Wagg C, Feng G, Walder F (2020) Symbiotic soil fungi enhance resistance and resilience of an experimental grassland to drought and nitrogen deposition. J Ecol 00:1-11. https://doi.org/10.1111/1365-2745.13521

Karaca H (2012) Buffering effect of elemental sulfur on mycorrhizal infection of leek. J Plant Nutr 35:678-687. https://doi.org/10. 1080/01904167.2012.653073

Klironomos J (2003) Variation in plant response to native and exotic arbuscular mycorrhizal fungi. Ecol 84:2292-2301. https://doi. org/10.1890/02-0413

Koch A, Antunes P, Maherali H, Hart M, Klironomos J (2017) Evolutionary asymmetry in the arbuscular mycorrhizal symbiosis: conservatism in fungal morphology does not predict host plant growth. New Phytol 214:1330-1337. https://doi.org/10.1111/ nph. 14465

Koch A, Croll D, Sanders I (2006) Genetic variability in a population of arbuscular mycorrhizal fungi causes variation in plant growth. Ecol Lett 9:103-110. https://doi.org/10.1111/j.1461-0248.2005. 00853.x

Kohler-Milleret R, Le Bayon R, Chenu C, Gobat J, Boivin P (2013) Impact of two root systems, earthworms and mycorrhizae on the physical properties of an unstable silt loam Luvisol and plant production. Plant Soil 370:251-265. https://doi.org/10.1007/ s11104-013-1621-4

Koske R, Tessier B (1983) A convenient permanent slide mounting medium. Newsletter Mycol Soc Amer 34:59

Krüger M, Krüger C, Walker C, Stockinger H, Schüßler A (2012) Phylogenetic reference data for systematics and phylotaxonomy of arbuscular mycorrhizal fungi from phylum to species-level. New Phytol 193:970-984. https://doi.org/10.1111/j.1469-8137.2011. 03962.x

Krüger M, Stockinger H, Krüger C, Schüssler A (2009) DNA-based species level detection of Glomeromycota: one PCR primer set 
for all arbuscular mycorrhizal fungi. New Phytol 183:212-223. https://doi.org/10.1111/j.1469-8137.2009.02835.x

Larkin M, Blackshields G, Brown N, Chenna R, McGettigan P, McWilliam H, Valentin F, Wallace I, Wilm A, Lopez R, Thompson JD, Gibson TJ, Higgins DG (2007) Clustal W and clustal X version 2.0. Bioinform 23:2947-2948. https://doi.org/10.1093/Bioinform/btm404

Lendenmann M, Thonar C, Barnard R, Salmon Y, Werner R, Frossard E, Jansa J (2011) Symbiont identity matters: carbon and phosphorus fluxes between Medicago truncatula and different arbuscular mycorrhizal fungi. Mycorrhiza 21:689-702. https://doi.org/10.1007/s00572-011-0371-5

McGonigle T, Miller M, Evans D, Fairchild G, Swan J (1990) A new method which gives an objective-measure of colonization of roots by vesicular arbuscular mycorrhizal fungi. New Phytol 115:495501. https://doi.org/10.1111/j.1469-8137.1990.tb00476.x

Mensah J, Koch A, Antunes P, Kiers E, Hart M, Bucking H (2015) High functional diversity within species of arbuscular mycorrhizal fungi is associated with differences in phosphate and nitrogen uptake and fungal phosphate metabolism. Mycorrhiza 25:533-546. https://doi.org/10.1007/s00572-015-0631-x

Milne I, Wright F, Rowe G, Marshall D, Husmeier D, McGuire G (2004) TOPALi: software for automatic identification of recombinant sequences within DNA multiple alignments. Bioinform 20:1806-1807. https://doi.org/10.1093/Bioinform/ bth 155

Morton JB, Redecker D (2001) Tew new families of Glomales Archaeosporaceae and Paraglomeraceae with two new Genera Archaeospora and Paraglomus based on concordant molecular and morphological characters. Mycologia 93:181-195. https://doi.org/10. 1080/00275514.2001.12063147

Mosse B (1962) Establishment of vesicular-arbuscular mycorrhiza under aseptic conditions. J Gen Microbiol 27:509-520. https:// doi.org/10.1099/00221287-27-3-509

Munkvold L, Kjoller R, Vestberg M, Rosendahl S, Jakobsen I (2004) High functional diversity within species of arbuscular mycorrhizal fungi. New Phytol 164:357-364. https://doi.org/10.1111/j. 1469-8137.2004.01169.x

Oehl F, Laczko E, Bogenrieder A, Stahr K, Bosch R, van der Heijden MAG, Sieverding E (2010) Soil type and land use intensity determine the composition of arbuscular mycorrhizal fungal communities. Soil Biol Biochem 42:724-738. https://doi.org/10.1016/j. soilbio.2010.01.006

Oehl F, Laczko E, Oberholzer HR, Jansa J, Egli S (2017) Diversity and biogeography of arbuscular mycorrhizal fungi in agricultural soils. Biol Fertil Soils 53:777-797. https://doi.org/10.1007/ s00374-017-1217-x

Oehl F, Sánchez-Castro I, Palenzuela J, Silva GA, Sieverding E (2014a) Glomus compressum, a new arbuscular mycorrhizal fungus from different agro-ecosystems in Central Europe. Nova Hedwigia 99:429-439. https://doi.org/10.1127/0029-5035/2014/0200

Oehl F, Sánchez-Castro I, Santos VM, Silva GA, Palenzuela J (2019a) Archaeospora europaea: a new arbuscular mycorrhizal fungus from France Germany Italy and Switzerland with a key to the Archaeosporaceae species. Sydowia 71:129-137. https://doi.org/ 10.12905/0380.sydovvia71-2019-0129

Oehl F, Sánchez-Castro I, Silva DKA, Santos VM, Palenzuela J, Silva GA (2019b) Septoglomus nigrum: a new arbuscular mycorrhizal fungus from France Germany and Switzerland. Nova Hedwigia 109:121-134. https://doi.org/10.1127/nova_hedwigia/2019/0523

Oehl F, Sieverding E, Ineichen K, Ris EA, Boller T, Wiemken A (2005) Community structure of arbuscular mycorrhizal fungi at different soil depths in extensively and intensively managed agroecosystems. New Phytol 165:273-283. https://doi.org/10.1111/j.14698137.2004.01235.x

Oehl F, Sieverding E, Ineichen K, Mäder P, Wiemken A, Boller T (2009) Distinct sporulation dynamics of arbuscular mycorrhizal fungal communities from different agroecosystems in long-term microcosms. Agric Ecosyst Environ 134:257-268. https://doi. org/10.1016/j.agee.2009.07.008

Oehl F, Sieverding E, Palenzuela J, Ineichen K, da Silva G (2011a) Advances in Glomeromycota taxonomy and classification. IMA Fungus 2:191-199. https://doi.org/10.5598/imafungus.2011.02.02.10

Oehl F, Silva GA, Goto B, Maia L, Sieverding E (2011b) Glomeromycota: two new classes and a new order. Mycotaxon 116:365-379. https://doi.org/10.5248/116.365

Oehl F, Tchabi A, Silva GA, Sánchez-Castro I, Palenzuela J, Monte Júnior IP, Lawouin L, Coyne D, Hountondji F (2014b) Acaulospora spinosissima: a new arbuscular mycorrhizal fungus from the Southern Guinea Savanna in Benin. Sydowia 66:29-42. https:// doi.org/10.12905/0380.sydowia66(1)2014-0029

Oliveira R, Vosátka M, Dodd J, Castro P (2005) Studies on the diversity of arbuscular mycorrhizal fungi and the efficacy of two native isolates in a highly alkaline anthropogenic sediment. Mycorrhiza 16:23-31. https://doi.org/10.1007/s00572-005-0010-0

Ortas I, Sari N, Akpinar C, Yetisir H (2013) Selection of Arbuscular Mycorrhizal Fungi Species for Tomato Seedling Growth Mycorrhizal Dependency and Nutrient Uptake. Eur J Hortic Sci 78:209-218

Palenzuela J, Azcón-Aguilar C, Barea J, da Silva G, Oehl F (2013) Septoglomus altomontanum : a new arbuscular mycorrhizal fungus from mountainous and alpine areas in Andalucia (southern Spain). IMA Fungus 4:243-249. https://doi.org/10.5598/imafungus.2013. 04.02.09

Palenzuela J, Azcón-Aguilar C, Berea J, da Silva G, Oehl F (2015) Acaulospora baetica a new arbuscular mycorrhizal fungal species from two mountain ranges in Andalucia (Spain). Nova Hedwigia 101:463-474. https://doi.org/10.1127/nova_hedwigia/2015/0285

Plenchette C, Furlan V, Fortin J (1982) Effects of different endomycorrhizal fungi on 5 host plants grown on calcined montmorillonite clay. J Am Soc Hortic Sci 107:535-538

Pohlert T (2021) PMCMRplus: Calculate Pairwise Multiple Comparisons of Mean Rank Sums Extended. R package version 1.9.0

Powell J, Parrent J, Hart M, Klironomos J, Rillig M, Maherali H (2009) Phylogenetic trait conservatism and the evolution of functional trade-offs in arbuscular mycorrhizal fungi. Proc Royal Soc B 276:4237-4245. https://doi.org/10.1098/rspb.2009.1015

Pringle A, Bever J (2008) Analogous effects of arbuscular mycorrhizal fungi in the laboratory and a North Carolina field. New Phytol 180:162-175. https://doi.org/10.1111/j.1469-8137.2008.02537.x

R Core Team (2021) R: A Language and Environment for Statistical Computing. R Foundation for Statistical Computing, Vienna

Redecker D, Kodner R, Graham L (2000a) Glomalean Fungi from the Ordovician Sci 289:1920-1921. https://doi.org/10.1126/science. 289.5486.1920

Redecker D, Morton J, Bruns T (2000b) Ancestral lineages of arbuscular mycorrhizal fungi (Glomales). Mol Phylogenet Evol 14:276284. https://doi.org/10.1006/mpev.1999.0713

Rillig M, Mummey D (2006) Mycorrhizas and soil structure. New Phytol 171:41-53. https://doi.org/10.1111/j.1469-8137.2006. 01750.x

Ronquist F, Huelsenbeck J (2003) MrBayes 3: Bayesian phylogenetic inference under mixed models. Bioinform 19:1572-1574. https:// doi.org/10.1093/Bioinform/btg180

Sieverding E (1991) Vesicular-arbuscular mycorrhiza management in tropical agrosystems. Deutsche Gesellschaft für Technische Zusammenarbeit Nr 224 Hartmut Bremer Verlag, Friedland

Sieverding E, da Silva G, Berndt R, Oehl F (2014) Rhizoglomus, a new genus of the Glomeraceae. Mycotaxon 129:373-386. https://doi. org/10.5248/129.373

Sieverding E, Howeler RH (1985) Influence of species of VA mycorrhizal fungi on cassava yield response to phosphorus fertilization. Plant Soil 88:213-221. https://doi.org/10.1007/BF02182447 
Silva GA, Maia LC, Oehl F (2012) Phylogenetic systematics of the Gigasporales. Mycotaxon 122:207-220. https://doi.org/10.5248/ 122.207

Smith S, Read D (2008) Mycorrhizal Symbiosis, 3rd edn. Academic Press, Cambridge, pp 1-787

Smith S, Smith F, Jakobsen I (2004) Functional diversity in arbuscular mycorrhizal (AM) symbioses: the contribution of the mycorrhizal P uptake pathway is not correlated with mycorrhizal responses in growth or total P uptake. New Phytol 162:511-524. https://doi.org/10.1111/j.1469-8137.2004.01039.x

Solaiman M, Saito A (2001) Phosphate efflux from intraradical hyphae of Gigaspora margarita in vitro and its implication for phosphorus translocation. New Phytol 151:525-533. https://doi.org/10. 1046/j.0028-646x.2001.00182.x

Sorensen J, Larsen J, Jakobsen I (2008) Pre-inoculation with arbuscular mycorrhizal fungi increases early nutrient concentration and growth of field-grown leeks under high productivity conditions. Plant Soil 307:135-147. https://doi.org/10.1007/ s11104-008-9591-7

Takács T (2012) Site-specific optimization of arbuscular mycorrhizal fungi mediated phytoremediation. In: Zaidi A, Wani P, Khan M (eds) Toxicity of Heavy Metals to Legumes and Bioremediation. Springer, Vienna, pp 179-202

Tedersoo L, Sanchez-Ramirez S, Koljalg U, Bahram M, Doring M, Schigel D, Abarenkov K (2018) High-level classification of the fungi and a tool for evolutionary ecological analyses. Fungal Divers 90:135-159. https://doi.org/10.1007/s13225-018-0401-0

Tchabi A, Coyne D, Hountondji F, Lawouin L, Wiemken A, Oehl F (2010) Efficacy of indigenous arbuscular mycorrhizal fungi for promoting white yam (Dioscorea rotundata) growth in West Africa. Appl Soil Ecol 45:92-100. https://doi.org/10.1016/j. apsoil.2010.03.001

Thonar C, Schnepf A, Frossard E, Roose T, Jansa J (2011) Traits related to differences in function among three arbuscular mycorrhizal fungi. Plant Soil 339:231-245. https://doi.org/10.1007/ s11104-010-0571-3

Treseder K (2013) The extent of mycorrhizal colonization of roots and its influence on plant growth and phosphorus content. Plant Soil 371:1-13. https://doi.org/10.1007/s11104-013-1681-5

van der Heijden MGA, Boller T, Wiemken A, Sanders I (1998a) Different arbuscular mycorrhizal fungal species are potential determinants of plant community structure. Ecol 79:2082-2209. https://doi.org/10.1890/0012-9658(1998)079[2082:DAMFSA] 2.0.CO;2

van der Heijden MGA, Martin F, Selosse M, Sanders I (2015) Mycorrhizal ecology and evolution: the past the present and the future. New Phytol 205:1406-1423. https://doi.org/10.1111/nph.13288 van der Heijden MGA, Klironomos J, Ursic M, Moutoglis P, StreitwolfEngel R, Boller T, Wiemken A, Sanders I (1998b) Mycorrhizal fungal diversity determines plant biodiversity ecosystem variability and productivity. Nature 396:69-72. https://doi.org/10. 1038/23932

Verbruggen E, Roling W, Gamper H, Kowalchuk G, Verhoef H, van der Heijden MGA (2010) Positive effects of organic farming on below-ground mutualists: large-scale comparison of mycorrhizal fungal communities in agricultural soils. New Phytol 186:968979. https://doi.org/10.1111/j.1469-8137.2010.03230.x

Vierheilig H, Coughlan A, Wyss U, Piche Y (1998) Ink and vinegar, a simple staining technique for arbuscular-mycorrhizal fungi. Appl Environ Microbiol 64:5004-5007. https://doi.org/10.1128/AEM. 64.12.5004-5007.1998

White T, Bruns T, Lee S, Taylor J (1990) Amplification and direct sequencing of fungal ribosomal RNA genes for phylogenetics. In: Innis MA, Gelfand DH, Sninsky JJ, White TJ (eds) PCR Protocols: A Guide to Methods and Applications. Academic Press, San Diego, pp 315-322

Wickham H (2016) ggplot2: Elegant Graphics for Data Analysis. Springer-Verlag, New York

Wijayawardene N, Hyde K, Al-Ani L, Tedersoo L, Haelewaters D, Rajeshkumar KC, Zhao RL, Andre A, Saxena R, Tokarev Y et al (2020) Outline of fungi and fungus-like taxa. Mycosphere 11(1):1160-1456. https://doi.org/10.5943/mycosphere/11/1/8

Zeileis A, Cribari-Neto F, Gruen B, Kosmidis I, Simas AB, Rocha AV (2021) Package "betareg" version 3.1-4

Publisher's Note Springer Nature remains neutral with regard to jurisdictional claims in published maps and institutional affiliations. 